\title{
SRNL Phase 1 Assessment of the WTP Waste Qualification Program
}

\author{
D.K. Peeler \\ E.K. Hansen \\ C.C. Herman \\ S.L. Marra \\ W.R. Wilmarth
}

February 2012

Savannah River National Laboratory Savannah River Nuclear Solutions, LLC Aiken, SC 29808

Prepared for the U.S. Department of Energy under contract number DE-AC09-08SR22470. 
SRNL-STI-2011-00723

Revision 0

\section{DISCLAIMER}

This work was prepared under an agreement with and funded by the U.S. Government. Neither the U.S. Government or its employees, nor any of its contractors, subcontractors or their employees, makes any express or implied:

1. warranty or assumes any legal liability for the accuracy, completeness, or for the use or results of such use of any information, product, or process disclosed; or

2. representation that such use or results of such use would not infringe privately owned rights; or

3. endorsement or recommendation of any specifically identified commercial product, process, or service.

Any views and opinions of authors expressed in this work do not necessarily state or reflect those of the United States Government, or its contractors, or subcontractors.

\section{Printed in the United States of America}

Prepared for

U.S. Department of Energy 
Keywords: Hanford, WTP, LAW, HLW, pretreatment, qualification

Retention: Permanent

\title{
SRNL Phase 1 Assessment of the WTP Waste Qualification Program
}

\author{
D.K. Peeler \\ E.K. Hansen \\ C.C. Herman \\ S.L. Marra \\ W.R. Wilmarth
}

February 2012

Savannah River National Laboratory Savannah River Nuclear Solutions, LLC Aiken, SC 29808

Prepared for the U.S. Department of Energy under contract number DE-AC09-08SR22470. 


\section{REVIEWS AND APPROVALS}

AUTHORS:

D.K. Peeler, Process Technology Programs

Date

E.K. Hansen, Process Technology Programs

Date

W.R. Wilmarth, Environmental Management

Date

C.C. Herman, Manager

Date

Process Technology Programs

S.L. Marra, Manager

Date

Environmental \& Chemical Process Technology Research Programs 
SRNL-STI-2011-00723

Revision 0

\section{EXECUTIVE SUMMARY}

The Hanford Tank Waste Treatment and Immobilization Plant (WTP) Project is currently transitioning its emphasis from an engineering design and construction phase toward facility completion, start-up and commissioning. With this transition, the WTP Project has initiated more detailed assessments of the requirements that must be met during the actual processing of the Hanford Site tank waste. One particular area of interest is the waste qualification program. In general, the waste qualification program involves testing and analysis to demonstrate compliance with waste acceptance criteria, determine waste processability, and demonstrate laboratory-scale unit operations to support WTP operations. The testing and analysis are driven by data quality objectives (DQO) requirements necessary for meeting waste acceptance criteria for transfer of high-level wastes from the tank farms to the WTP, and for ensuring waste processability including proper glass formulations during processing within the WTP complex.

Given the successful implementation of similar waste qualification efforts at the Savannah River Site (SRS) which were based on critical technical support and guidance from the Savannah River National Laboratory (SRNL), WTP requested subject matter experts (SMEs) from SRNL to support a technology exchange with respect to waste qualification programs in which a critical review of the WTP program could be initiated and lessons learned could be shared. The technology exchange was held on July 18 - 20, 2011 in Richland, Washington, and was the initial step in a multi-phased approach to support development and implementation of a successful waste qualification program at the WTP. The 3-day workshop was hosted by WTP with representatives from the Tank Operations Contractor (TOC) and SRNL in attendance as well as representatives from the US DOE Office of River Protection (ORP) and the Defense Nuclear Facility Safety Board (DNFSB) Site Representative office. The purpose of the workshop was to share lessons learned and provide a technology exchange to support development of a technically defensible waste qualification program.

The objective of this report is to provide a review, from SRNL's perspective, of the WTP waste qualification program as presented during the workshop. In addition to SRNL's perspective on the general approach to the waste qualification program, more detailed insight into the specific unit operations presented by WTP during the workshop is provided. This report also provides a general overview of the SRS qualification program which serves as a basis for a comparison between the two programs. Recommendations regarding specific steps are made based on the review and SRNL's lessons learned from qualification of SRS low-activity waste (LAW) and high-level waste (HLW) to support maturation of the waste qualification program leading to WTP implementation. 


\section{TABLE OF CONTENTS}

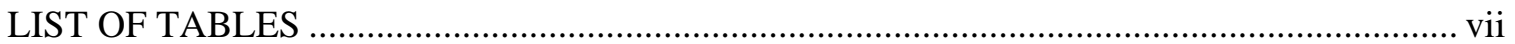

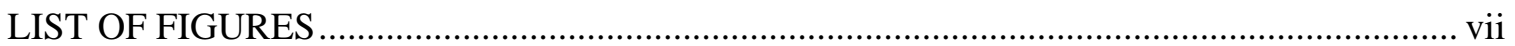

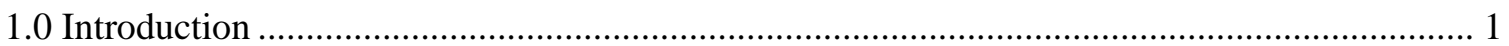

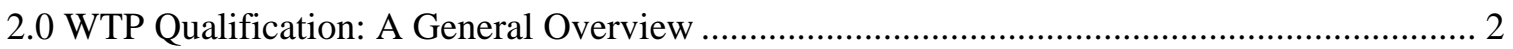

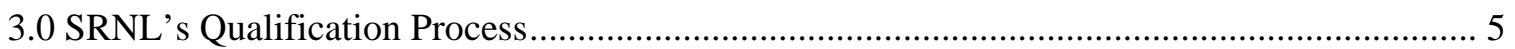

3.1 General Approach to Qualification and Feed Acceptance................................................... 5

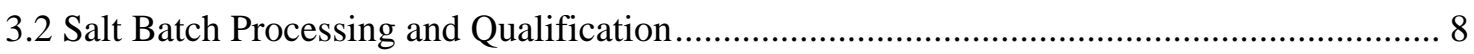

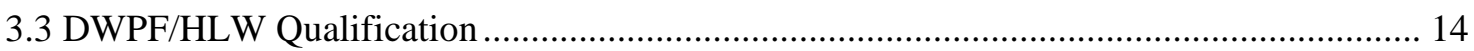

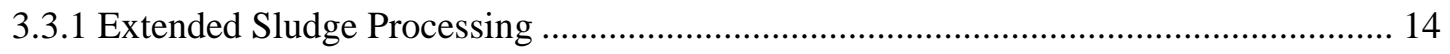

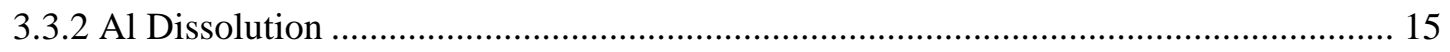

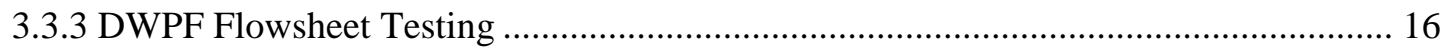

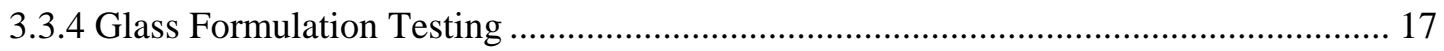

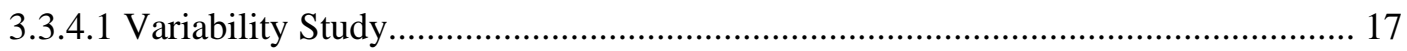

3.3.4.2 Qualification Glass: Shielded Cells Testing ...................................................... 18

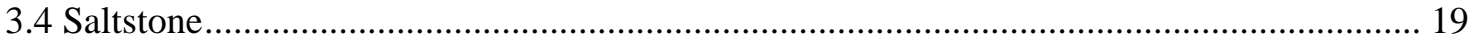

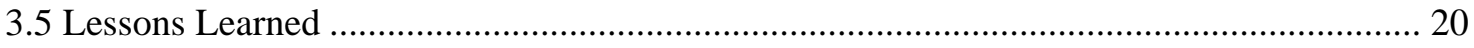

4.0 WTP Specific Unit Operations: An SRNL Perspective of Workshop Discussions ................ 22

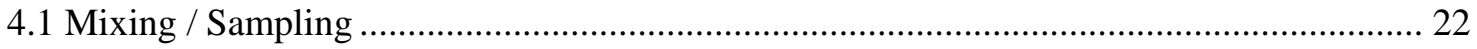

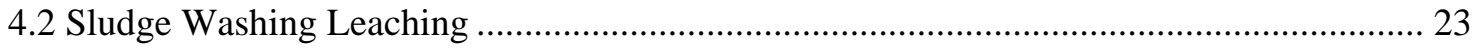

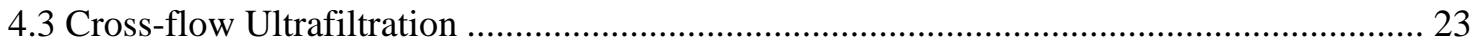

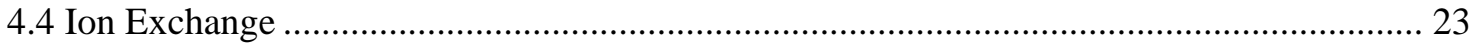

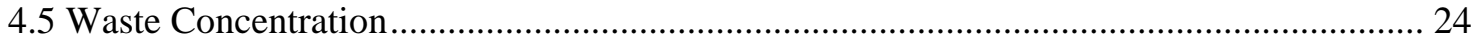

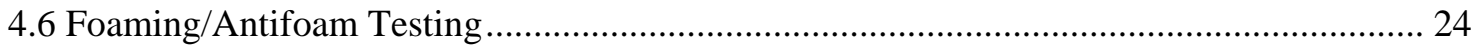

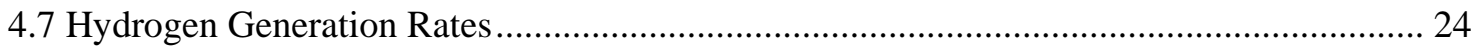

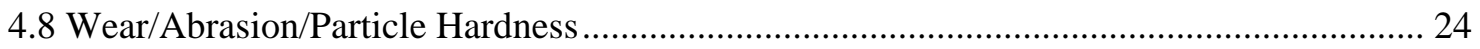

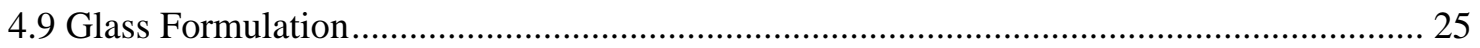

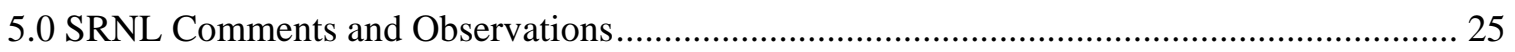

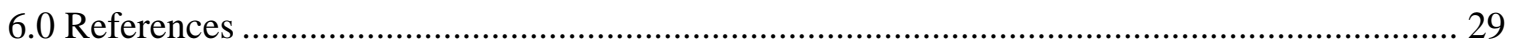




\section{LIST OF TABLES}

Table 3-1 - Required Radionuclides for Salt Batch Qualification.................................................9

Table 3-2 - Required Chemical Constituents for Salt Batch Qualification ..................................11

Table 3-3- Required WAC Analysis for ARP/MCU Qualification ............................................13

Table 3-4 - Nuclides Requiring Lower Detection Limits Post-Qualification Analyses ................14

Table 3-5 Tank 50 Samples Needed for Saltstone ..................................................................20

\section{LIST OF FIGURES}

Figure 2-1. High-Level Overview of the WTP WAC/Qualification and Process Control..............4

Figure 3-1. Flowchart of the SRS Waste Processing System....................................................

Figure A-1. Phase 1 Workshop Agenda (July 18, 2011)..................................................... A-2

Figure A-2. Phase 1 Workshop Agenda (July 19, 2011)....................................................... A-4

Figure A-3. Phase 1 Workshop Agenda (July 20, 2011) .......................................................... A-6 


\section{LIST OF ABBREVIATIONS}

\begin{tabular}{|c|c|}
\hline ARP & Actinide Removal Process \\
\hline BNI & Bechtel National, Inc. \\
\hline $\mathrm{BOF}$ & Balance of Facilities \\
\hline СРC & Chemical Process Cell \\
\hline CST & Crystalline Silicotitanate \\
\hline CUF & Cell Unit Filter \\
\hline DNFSB & Defense Nuclear Facility Safety Board \\
\hline DOE & Department of Energy \\
\hline DQO & Data Quality Objectives \\
\hline DSA & Documented Safety Analysis \\
\hline DWPF & Defense Waste Processing Facility \\
\hline EA & Environmental Assessment \\
\hline ESP & Extended Sludge Processing \\
\hline HLW & High Level Waste \\
\hline ICP-AES & Inductively Coupled Plasma - Atomic Emission Spectroscopy \\
\hline ICP-MS & Inductively Coupled Plasma - Mass Spectrometry \\
\hline LAB & Analytical Laboratory \\
\hline LA & Laser Ablation \\
\hline LAW & Low Activity Waste \\
\hline LLW & Low Level Waste \\
\hline MCU & Modular Caustic Side Solvent Extraction Unit \\
\hline MFT & Melter Feed Tank \\
\hline MST & Monosodium Titanate \\
\hline NCSE & Nuclear Criticality Safety Evaluation \\
\hline ORP & Office of River Protection \\
\hline PCCS & Product Composition Control System \\
\hline PEP & Pretreatment Engineering Platform \\
\hline PCT & Product Consistency Test \\
\hline PT & Pretreatment \\
\hline SCIX & Small Column Ion Exchange \\
\hline SME & Slurry Mix Evaporator \\
\hline SPF & Saltstone Production Facility \\
\hline SRAT & Sludge Receipt and Adjustment Tank \\
\hline SRNL & Savannah River National Laboratory \\
\hline
\end{tabular}




$\begin{array}{ll}\text { SRS } & \text { Savannah River Site } \\ \text { SWPF } & \text { Salt Waste Processing Facility } \\ \text { TOC } & \text { Tank Operations Contractor } \\ \text { TCLP } & \text { Toxicity Characteristic Leaching Procedure } \\ \text { UDQE } & \text { Unreviewed Disposal Question Evaluation } \\ \text { VHT } & \text { Vapor Phase Hydration Test } \\ \text { WAC } & \text { Waste Acceptance Criteria } \\ \text { WCS } & \text { Waste Characterization System } \\ \text { WTP } & \text { Hanford Tank Waste Treatment \& Immobilization Plant }\end{array}$


SRNL-STI-2011-00723

Revision 0

\subsection{Introduction}

The Hanford Tank Waste Treatment and Immobilization Plant (WTP) is a complex of radioactive waste treatment processing facilities designed and constructed by Bechtel National, Inc. (BNI) for the US Department of Energy (DOE). The WTP will process high level radioactive wastes located in the Hanford Site tank farms to separate as high level waste (HLW) sludge and low activity waste (LAW) supernatant. The processed HLW and LAW waste fractions will be immobilized into stable glass forms. The HLW glass will be stored for eventual shipment to the federal waste repository. The LAW glass will be maintained at the Hanford reservation. The Hanford tank wastes contain approximately 190 million curies in 56 million gallons of highly radioactive and mixed hazardous waste stored underground at the Hanford Site. The tank waste includes solids (sludge), liquid (supernatant), and salt cake (dried salts that will dissolve in water, forming supernatant). The WTP will process the radioactive and hazardous tank waste to meet regulatory requirements for disposal.

The DOE Office of River Protection (ORP) in Richland, Washington, is responsible for the activities necessary to remediate the Hanford tank waste. Through the WTP Prime Contract, BNI manages and oversees the design, construction, and commissioning of the WTP Project which includes five major facilities:

- Analytical Laboratory (LAB)

- Low-Activity Waste (LAW)

- High-Level Waste (HLW)

- Pretreatment (PT)

- Balance of Facilities (BOF)

The WTP Project is currently transitioning its emphasis from an engineering design and construction phase toward facility completion, start-up and commissioning. With this transition, the WTP Project has initiated more detailed assessments of the requirements that must be met during the actual processing of the Hanford Site tank waste. One particular area of interest is the waste qualification program. In general, the waste qualification program involves testing and analysis to demonstrate compliance with waste acceptance criteria, determine waste processability, and demonstrate laboratory-scale unit operations. The testing and analysis are driven by data quality objectives (DQO) necessary to ensure meeting a) waste acceptance criteria for transfer of high-level wastes from the tank farms to the WTP, b) waste processability including proper glass formulations, and c) design and nuclear safety requirements during processing within the WTP complex.

Given the successful implementation of similar waste qualification efforts at the Savannah River Site (SRS), which were based on critical technical support and guidance from the Savannah River National Laboratory (SRNL), WTP personnel requested subject matter experts (SMEs) from SRNL to support a technology exchange with respect to waste qualification programs in which a critical review of the WTP program could be initiated and lessons learned could be shared. ${ }^{\mathrm{i}}$ The technology exchange was held on July 18 - 20, 2011 in Richland, Washington, and was the initial step in a multi-phased approach to support development and implementation of a successful

\footnotetext{
${ }^{\mathrm{i}}$ Hanford Tank Waste Treatment and Immobilization Plant, IEWO M0SRV00028, Amendment 15, Feed Qualification, Scope of Work and Technical Requirements, SCT-M0SRV00028-00-007, Revision 0.
} 
waste qualification program at the WTP. ${ }^{\text {ii }}$ The 3-day workshop was hosted by WTP personnel with representatives from the Tank Operations Contractor (TOC) and SRNL in attendance as well as representatives from the US DOE ORP and the Defense Nuclear Facility Safety Board (DNFSB) Site Representative office. The purpose of the workshop was to share lessons learned and provide a technology exchange to support development of a technically defensible waste qualification program. The agenda for the three-day workshop is shown in Appendix A.

Specific topics covered during the workshop included:

o WAC-DQO analytes

o Mixing / Sampling

o Sludge washing and leaching

o Ion exchange

o Crossflow Ultrafiltration

o Boil down

o Foaming

o Hydrogen generation rates

o Wear/Abrasion/Particle Hardness

o LAW and HLW Glass

The objective of this report is to provide a review, from SRNL's perspective, of the WTP qualification program as presented during the workshop. In addition to SRNL's perspective on the general approach to the waste qualification program, more detailed insight into the specific unit operations presented by WTP personnel during the workshop is provided. This report also provides a general overview of the SRS qualification program, which serves as a basis for a comparison between the two programs, and lessons learned from SRS qualification programs are described. Lastly, recommendations are made regarding specific steps to support maturation of the WTP qualification program leading to implementation.

As previously mentioned, the workshop was the initial step in a phased approached to develop and implement a technically sound waste qualification program for the WTP. As a result of the workshop, additional Phase 1 scope was identified by the WTP-SRNL team. The additional scope included critical reviews by SRNL of specific test methods and procedures which have been proposed to support analysis and testing of 260 WAC-DQO parameters identified as being needed to meet the qualification requirements. ${ }^{1}$ The results of SRNL's review of specific test methods and procedures are documented in a separate report. ${ }^{2}$ It is anticipated that future activities will mature the waste qualification program, including specification, fabrication, and configuration of the unit operations test apparatus.

\subsection{WTP Qualification: A General Overview}

Figure 2-1 provides a high-level overview of the WTP strategy for waste qualification and process control. The WTP design criteria, operational requirements, and tank waste characterization information are used to develop the Preliminary Campaign Sheet that identifies the plan for processing the waste feed campaign. This sheet includes the key parameters and unit operations associated with waste qualification testing. Staged waste from the tank farms is

ii The technology exchange is referred to as the Phase 1 workshop throughout this report. 
sampled, and the sample provided for qualification testing a minimum of 180 days prior to the expected transfer (see Reference 3, Section 2.3). ${ }^{3}$ The qualification strategy is based on a key fundamental assumption that the WTP will receive from the TOC a representative sample from a specific campaign before the TOC is to transfer waste to the WTP. Although the responsibility of obtaining a representative sample is a TOC function, SRNL recommends that WTP and the TOC ensure that the definition of "representative sample" is consistent between the two entities to mitigate any downstream issues that may arise due to differences in the definition. From the WTP standpoint, a Campaign is defined as a staged Tank Farm waste that has been isolated, prepared for sampling, and sampled for pending transfer to the WTP (a Campaign being very similar to a sludge batch at SRS).

Based on the testing program shown in the Preliminary Campaign Sheet and with a representative sample from the TOC, the WTP would then implement their qualification program.

The waste qualification program consists of three elements:

1. Analysis and/or characterization supporting waste acceptance for feed transfer that consists of 18 parameters such as bulk density, total organic carbon, and hydrogen generation rate. The specific parameters and associated action limits are defined in Table 4-1 of Reference 1$){ }^{1}$

2. Analysis and/or characterization supporting waste acceptance for processability that consists of 260 parameters such as transfer flow rate, abrasivity, chemical characterization, and radionuclide characterization. The specific parameters are also defined in the WAC DQO (specifically Table 4-2 of Reference 1). ${ }^{1}$

3. Demonstrations of selected unit operations within the PT facility, the LAW vitrification facility, and the HLW vitrification facility. For the PT facility, unit operations to be evaluated include waste concentration (boil-down), sludge washing and leaching, crossflow ultrafiltration, and ion exchange. For the LAW and HLW facilities, parameters to be evaluated would include measurement of rheological properties and composition of the melter feed. The models for defining the glass formulation for the campaign will be used as part of the qualification program. 


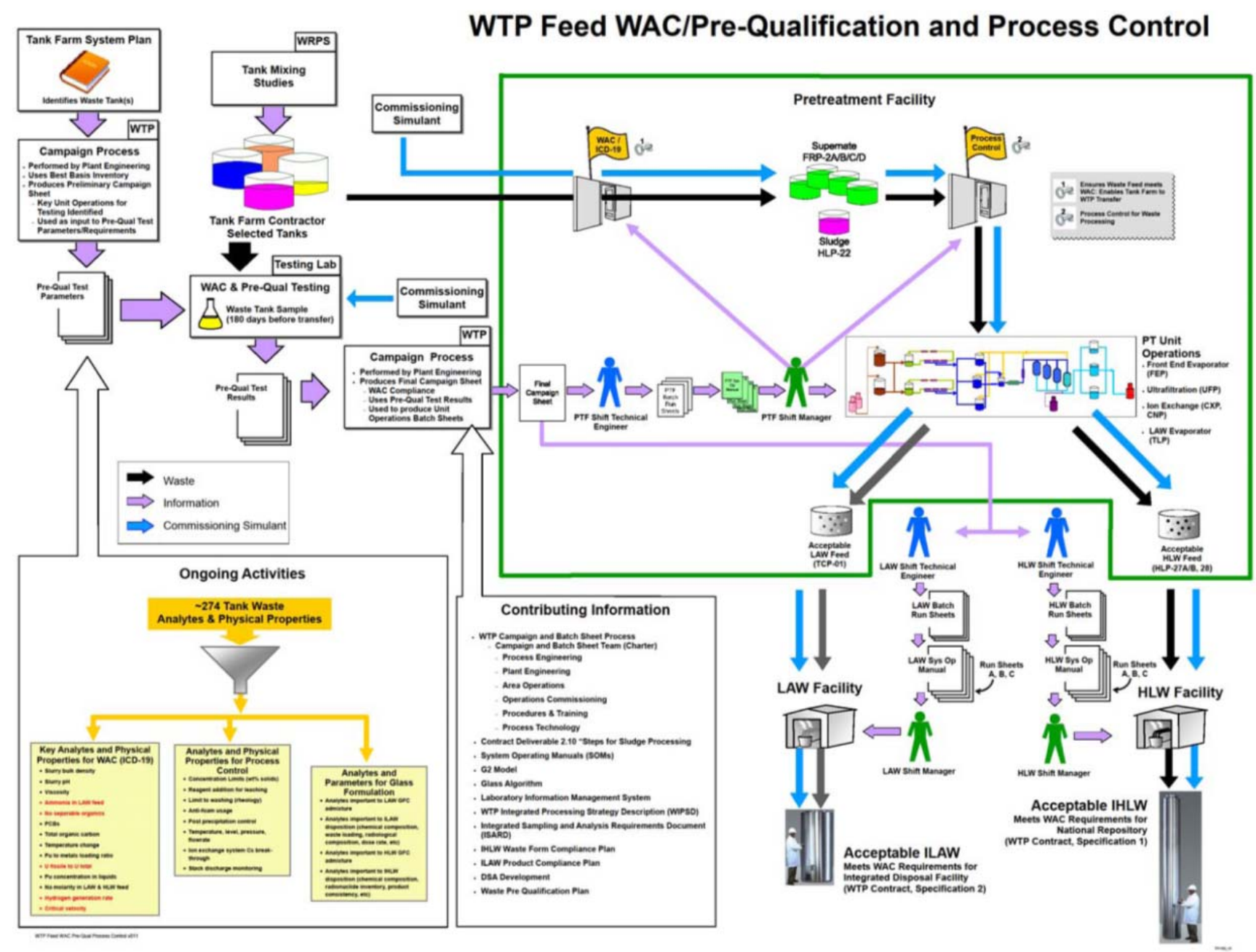

Figure 2-1. High-Level Overview of the WTP WAC/Qualification and Process Control. 
Analysis required to demonstrate compliance with waste acceptance criteria and processability must be completed within 180 days of sample receipt, and before delivery of waste to the WTP. ${ }^{3}$ The results of the WAC compliance data and the qualification testing program are used by WTP Plant Engineering personnel to develop a Final Campaign Sheet which defines the strategy that will be used to treat and process the corresponding waste Campaign. The Final Campaign Sheet serves as the basis for Batch Sheets which provide detailed information regarding flowsheet related parameters needed for waste treatment in each WTP unit operation. More specifically, the Batch Sheets, in conjunction with the System Operating Manuals, are intended to provide the data and parameters needed to operate each unit operation (e.g., sludge washing, ion exchange, crossflow ultrafiltration, and vitrification) to efficiently process the wastes through the WTP.

Based on the workshop discussions, SRNL believed that the intent of the qualification program was for process optimization. That is, the data and parameters that would be generated by the waste qualification program would allow WTP to "optimally" run each major unit operation as defined on the Batch Sheet. Subsequent discussions with WTP personnel on the specific program objectives have clarified the role of the Specification 12 testing and the unit operations testing. It is SRNL's current understanding that Specification 12 testing will be used to optimize the washing and leaching/dissolution of the batch with consideration to the projected quantities of HLW and LAW canisters to be produced. The remaining unit operations' demonstrations would then be used to confirm the unit operations and the integrated flowsheet.

\subsection{SRNL's Qualification Process}

In this section, a high-level overview is provided of the SRS liquid waste operations qualification process, which includes the basis for the steps and the objectives of the programs. Figure 3-1 provides a graphic flowchart for the SRS processes. In addition, details are provided for specific activities that are not directly part of the qualification program but are performed in support of the qualification process. These details provide the foundation for comparisons between the two approaches (WTP and SRS).

\subsection{General Approach to Qualification and Feed Acceptance}

Waste that is transferred from the Tank Farm to the processing facilities (i.e., Defense Waste Processing Facility (DWPF) and Saltstone) must meet a variety of processing, nuclear safety, design, and regulatory requirements to ensure that the waste can actually be processed effectively and that an acceptable product produced. The basic premise of the overall interface between facilities is that the waste being transferred is characterized well enough to ensure that the WAC have been met. These criteria have been developed by incorporating design, permitting, product quality, safety, and processing requirements. Some of these requirements are straight forward with firm limits (e.g., shielding requirements where dose values are calculated from radionuclide analysis). However, others have been defined as the result of development programs that support operating parameters (e.g., total solids of the sludge).

DWPF developed a Glass Product Control Program as part of its compliance strategy to demonstrate that it would produce an acceptable glass product. Part of that compliance strategy includes a qualification of waste activity. This qualification of waste activity ensures that the program bases for each sludge batch (or coupled operations with salt streams added) remain valid. The details of this effort are described in the sections that follow. The data generated during this qualification process provide insight to DWPF on the behavior of new batches of waste. This has 
been particularly beneficial for sludge batches that demonstrate changes in behavior relative to previous batches (e.g., differences in rheological properties or foaming). This program is not intended to provide direct operating parameters to the DWPF however. While new information will be gained during each batch qualification process it is critical that a strong technical basis exist for the processing limits that are set. These processing parameters must offer as much flexibility to DWPF as possible. The qualification process should be viewed as a confirmation and an opportunity to gain insight into the unexpected and offer insight into facility operations. Due to the tight time frame for this activity, it should not be viewed as a research and development program to generate innovative, technical baseline information. 


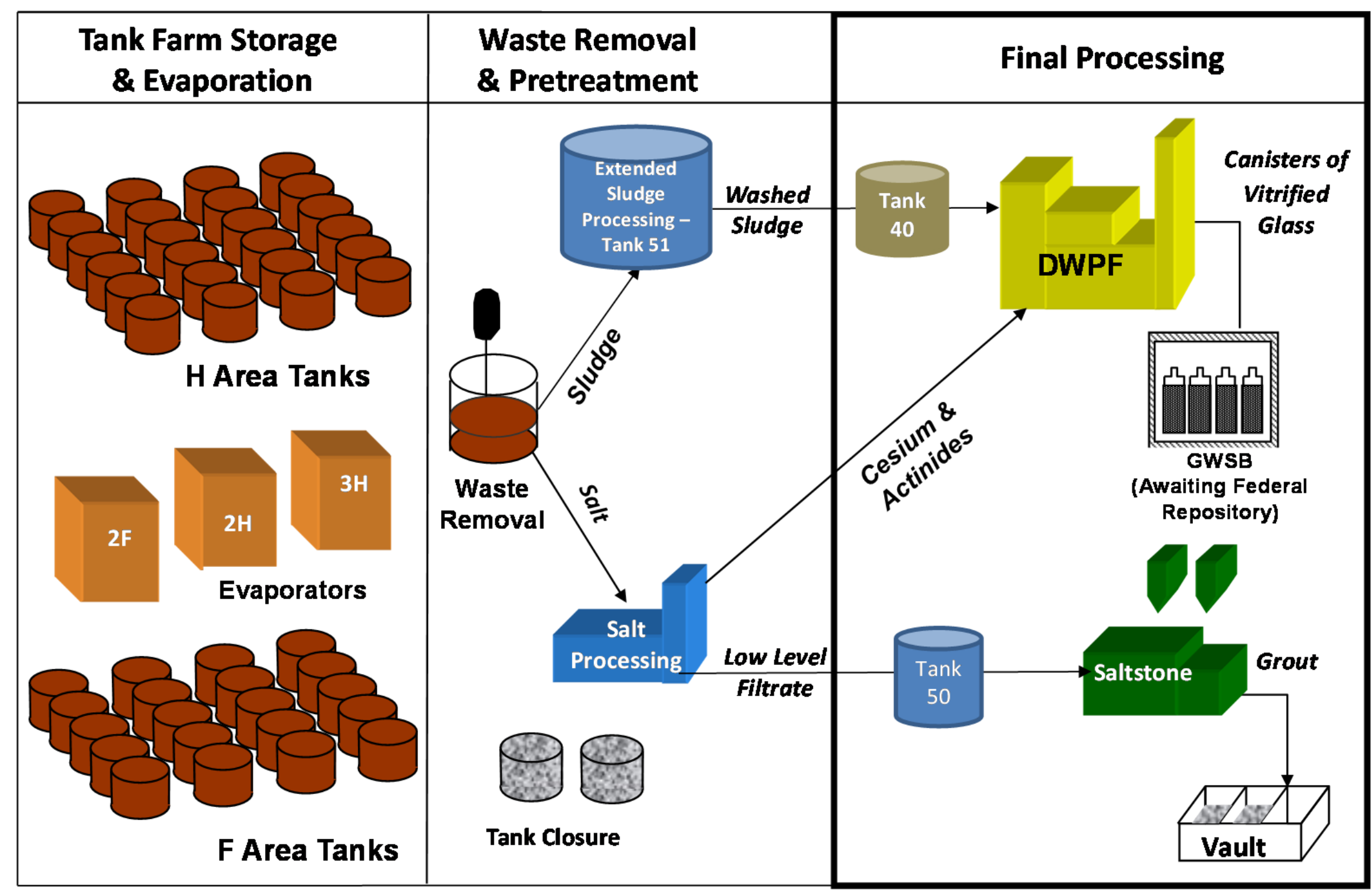

Figure 3-1. Flowchart of the SRS Waste Processing System. 


\subsection{Salt Batch Processing and Qualification}

The salt supernate or Low Level Waste (LLW) at the SRS is currently being treated in the Actinide Removal Process (ARP) facility and the Modular Caustic Side Solvent Extraction Unit (MCU) to remove the actinides and cesium from the supernate. Once the Salt Waste Processing Facility (SWPF) comes on line, equivalent processes will be performed in that facility at a much higher production rate. The ARP solids (monosodium titanate (MST) and entrained sludge solids) and the strip effluent containing the cesium are transferred to the DWPF for processing and incorporation into HLW glass.

Savannah River Remediation (SRR) is currently scheduled to qualify waste feed to the ARP/ MCU along with the SWPF when that facility becomes operational. For ARP/MCU, the following is accomplished in the qualification program. ${ }^{4}$ Qualification includes attributes for the Documented Safety Analysis (DSA) and WAC compliance, as well as assessment of processability of the waste. The qualification includes a Hazard Category calculation, an air emissions calculation, radiological evaluations, and confirmation of Nuclear Criticality Safety Evaluation (NCSE) compliance, a Saltstone WAC evaluation ${ }^{5}$, a DWPF WAC evaluation ${ }^{6}$, and a Tank Farm WAC evaluation ${ }^{7}$. Regardless of the operational facility, the sorbent - actinide removal and solvent extraction testing will be performed using the tank to be qualified.

Table 3-1 and Table 3-2 show radionuclide and chemical constituents addressed in each of the qualification requirement documents or calculations. ${ }^{\text {iii }}$ Saltstone targets requiring analyses in accordance with the Unreviewed Disposal Question Evaluation (UDQE) are noted with an "X, T" in the Saltstone column. $\mathrm{X}$ indicates the analyses required for batch qualification and $\mathrm{T}$ indicates the target. It should be noted that the Haz Cat column in Table 3-1 contains the criticality and radionuclide evaluations required for batch qualification at SRS. Table 3-3 shows the required radiological and chemical constituents at the lowest WAC limits.

In addition to the analytical characterization, a process performance test is used for qualifying the material for treatment in ARP/MCU. For the alpha removal test, a known volume of waste is obtained, and an amount of a qualified batch of monosodium titanate (MST) is added. The target MST concentration is that of the actual ARP process. The "qualification" of the supplied MST by SRNL prior to use by ARP is to ensure that the quality assurance components of the MST procurement process are completed. The slurry is agitated with laboratory mixers and sampled periodically to ensure that the alpha concentration will meet the WAC within the flowsheet duration. Secondly, the decontaminated tank waste is then tested using an ESS (extraction, scrub, and strip) protocol. This protocol simulates the chemistry within the solvent extraction process using typical phase ratios and measures the cesium distribution behavior. These measured distribution coefficients are compared to plant acceptance levels.

The process for qualification for SWPF has not been finalized but will likely be very similar to what is currently performed for ARP/MCU. For the Small Column Ion Exchange (SCIX) process, the outlined program was similar in concept to that used for ARP/MCU with batch contact used for both the MST and crystalline silicotitanate (CST) sorbents. The cesium distribution coefficient would be measured for a known waste to ion exchange material mass and compared to a plant acceptance level.

\footnotetext{
iii The solid waste acceptance criteria shown in Table 3-1 and Table 3-2 are associated with SRS site disposal.
} 
Table 3-1 - Required Radionuclides for Salt Batch Qualification

\begin{tabular}{|c|c|c|c|c|c|c|}
\hline Radionuclides & Saltstone & DWPF & SW & Haz Cat & Tank Farm & Air \\
\hline H-3 & $\mathrm{X}$ & - & $\mathrm{X}$ & - & $\mathrm{X}$ & $\mathrm{X}$ \\
\hline $\mathrm{C}-14$ & $\mathrm{X}$ & - & $\mathrm{X}$ & - & $\mathrm{X}$ & $\mathrm{X}$ \\
\hline Ni-63 & $\mathrm{X}$ & - & - & - & $\mathrm{X}$ & $\mathrm{X}$ \\
\hline Sr-90/Y-90 & $\mathrm{X}$ & $\mathrm{X}$ & $\mathrm{X}$ & $\mathrm{X}$ & $\mathrm{X}$ & $\mathrm{X}$ \\
\hline Tc-99 & $\mathrm{X}$ & - & $\mathrm{X}$ & $\mathrm{X}$ & $\mathrm{X}$ & $\mathrm{X}$ \\
\hline I-129 & $\mathrm{X}$ & - & $\mathrm{X}$ & $\mathrm{X}$ & - & $\mathrm{X}$ \\
\hline Cs-137/Ba-137m & $\mathrm{X}$ & $\mathrm{X}$ & $\mathrm{X}$ & $\mathrm{X}$ & $\mathrm{X}$ & $\mathrm{X}$ \\
\hline U-233 & $\mathrm{X}$ & $\mathrm{X}$ & $\mathrm{X}$ & - & $\mathrm{X}$ & $\mathrm{X}$ \\
\hline $\mathrm{U}-235$ & $\mathrm{X}$ & - & $\mathrm{X}$ & - & - & $\mathrm{X}$ \\
\hline Pu-241 & $\mathrm{X}$ & $\mathrm{X}$ & $\mathrm{X}$ & $\mathrm{X}$ & $\mathrm{X}$ & $\mathrm{X}$ \\
\hline Total Alpha & $\mathrm{X}$ & $\mathrm{X}$ & $\mathrm{X}$ & $\mathrm{X}$ & $\mathrm{X}$ & $\mathrm{X}$ \\
\hline Total Gamma & $\mathrm{T}$ & - & $\mathrm{X}$ & $\mathrm{X}$ & $\mathrm{X}$ & $\mathrm{X}$ \\
\hline Na-22 & $\mathrm{T}$ & - & - & - & - & - \\
\hline Al-26 & $\mathrm{T}$ & - & - & - & - & - \\
\hline Co-60 & $\mathrm{T}$ & $\mathrm{X}$ & - & $\mathrm{X}$ & $\mathrm{X}$ & $\mathrm{X}$ \\
\hline Ni-59 & $\mathrm{X}, \mathrm{T}$ & - & - & - & - & - \\
\hline Se-79 & $\mathrm{T}$ & - & - & - & - & - \\
\hline Nb-93m & $\mathrm{T}$ & - & - & - & - & - \\
\hline Nb-94 & $\mathrm{X}, \mathrm{T}$ & - & - & - & - & $\mathrm{X}$ \\
\hline Mo-93 & $\mathrm{T}$ & - & - & - & - & - \\
\hline Ru-106/Rh-106 & $\mathrm{T}$ & $\mathrm{X}$ & - & - & $\mathrm{X}$ & $\mathrm{X}$ \\
\hline $\mathrm{Sb}-125$ & $\mathrm{~T}$ & $\mathrm{X}$ & - & $\mathrm{X}$ & $\mathrm{X}$ & $\mathrm{X}$ \\
\hline Sn-126 & $\mathrm{T}$ & - & - & - & $\mathrm{X}$ & $\mathrm{X}$ \\
\hline Cs-134 & $\mathrm{T}$ & $\mathrm{X}$ & - & $\mathrm{X}$ & $\mathrm{X}$ & $\mathrm{X}$ \\
\hline Cs-135 & $\mathrm{X}, \mathrm{T}$ & - & - & $\mathrm{X}$ & $\mathrm{X}$ & - \\
\hline Ce-144/Pr-144 & $\mathrm{X}, \mathrm{T}$ & $\mathrm{X}$ & - & - & - & $\mathrm{X}$ \\
\hline Pm-147 & $\mathrm{T}$ & $\mathrm{X}$ & - & - & $\mathrm{X}$ & - \\
\hline Sm-151 & $\mathrm{T}$ & - & - & - & - & $\mathrm{X}$ \\
\hline Eu-152 & $\mathrm{T}$ & - & - & - & - & - \\
\hline Eu-154 & $\mathrm{T}$ & $\mathrm{X}$ & - & $\mathrm{X}$ & $\mathrm{X}$ & $\mathrm{X}$ \\
\hline Eu-155 & $\mathrm{T}$ & - & - & $\mathrm{X}$ & $\mathrm{X}$ & $\mathrm{X}$ \\
\hline Ra-226 & $\mathrm{T}$ & - & - & - & - & - \\
\hline Th-229 & $\mathrm{T}$ & - & - & - & - & - \\
\hline Th-230 & $\mathrm{X}, \mathrm{T}$ & - & - & - & - & - \\
\hline Th-232 & $\mathrm{T}$ & - & - & - & - & - \\
\hline U-232 & $\mathrm{X}, \mathrm{T}$ & - & - & - & - & $\mathrm{X}$ \\
\hline U-234 & $\mathrm{T}$ & - & $\mathrm{X}$ & - & $\mathrm{X}$ & $\mathrm{X}$ \\
\hline $\mathrm{U}-236$ & $\mathrm{X}, \mathrm{T}$ & - & - & - & $\mathrm{X}$ & $\mathrm{X}$ \\
\hline $\mathrm{U}-238$ & $\mathrm{~T}$ & - & - & - & $\mathrm{X}$ & $\mathrm{X}$ \\
\hline Np-237 & $\mathrm{T}$ & - & $\mathrm{X}$ & - & $\mathrm{X}$ & $\mathrm{X}$ \\
\hline Pu-238 sol/total & $\mathrm{T}$ & $\mathrm{X}$ & $\mathrm{X}$ & $\mathrm{X}$ & $\mathrm{X}$ & $\mathrm{X}$ \\
\hline Pu-239 & $\mathrm{T}$ & $\mathrm{X}$ & $\mathrm{X}$ & $\mathrm{X}$ & $\mathrm{X}$ & $\mathrm{X}$ \\
\hline Pu-240 & $\mathrm{T}$ & $\mathrm{X}$ & $\mathrm{X}$ & $\mathrm{X}$ & $\mathrm{X}$ & $\mathrm{X}$ \\
\hline Pu-242 & $\mathrm{X}, \mathrm{T}$ & - & $\mathrm{X}$ & $\mathrm{X}$ & $\mathrm{X}$ & $\mathrm{X}$ \\
\hline
\end{tabular}


SRNL-STI-2011-00723

Revision 0

Table 3-1 (continued) - Required Radionuclides for Salt Batch Qualification

\begin{tabular}{|c|c|c|c|c|c|c|}
\hline Radionuclides & Saltstone & DWPF & SW & Haz Cat & Tank Farm & Air \\
\hline Pu-244 & T & - & - & - & X & - \\
\hline Am-241 & T & X & X & - & X & X \\
\hline Am-242m & T & - & - & - & - & - \\
\hline Am-243 & X, T & - & - & - & X & X \\
\hline Cm-242 & T & - & - & - & - & - \\
\hline Cm-243 & X, T & - & - & - & - & - \\
\hline Cm-244 & - & X & - & - & X & X \\
\hline Cm-245 & - & - & - & - & X & X \\
\hline Total Beta & - & - & X & X & X & X \\
\hline
\end{tabular}

Notes: SW - Solid Waste acceptance criteria, Haz Cat - Facility Hazard Category Criteria, Air - Air Emissions Criteria. X - indicates the analyses required for batch qualification. T - indicates the target. 
SRNL-STI-2011-00723

Revision 0

Table 3-2 - Required Chemical Constituents for Salt Batch Qualification

\begin{tabular}{|c|c|c|c|c|}
\hline Constituents & Saltstone & DWPF & SW & Tank Farm \\
\hline $\mathbf{N H}_{4}$ & $\mathrm{X}$ & - & - & - \\
\hline $\mathrm{CO}_{3}$ & $\mathrm{X}$ & $\mathrm{X}$ & - & - \\
\hline $\mathbf{C l}$ & $\mathrm{X}$ & $\mathrm{X}$ & - & $\mathrm{X}$ \\
\hline $\mathbf{F}$ & $\mathrm{X}$ & $\mathrm{X}$ & - & $\mathrm{X}$ \\
\hline $\mathbf{O H}$ & $\mathrm{X}$ & $\mathrm{X}$ & - & $\mathrm{X}$ \\
\hline $\mathrm{NO}_{3}$ & $\mathrm{X}$ & $\mathrm{X}$ & - & $\mathrm{X}$ \\
\hline $\mathrm{NO}_{2}$ & $\mathrm{X}$ & $\mathrm{X}$ & - & $\mathrm{X}$ \\
\hline $\mathrm{C}_{2} \mathrm{O}_{4}$ & $\mathrm{X}$ & - & - & - \\
\hline $\mathrm{PO}_{4}$ & $\mathrm{X}$ & $\mathrm{X}$ & - & $\mathrm{X}$ \\
\hline $\mathrm{SO}_{4}$ & $\mathrm{X}$ & $\mathrm{X}$ & - & $\mathrm{X}$ \\
\hline As & $\mathrm{X}$ & - & $\mathrm{X}$ & - \\
\hline $\mathbf{B a}$ & $\mathrm{X}$ & - & $\mathrm{X}$ & - \\
\hline Cd & $\mathrm{X}$ & - & $\mathrm{X}$ & - \\
\hline $\mathrm{Cr}$ & $\mathrm{X}$ & $\mathrm{X}$ & $\mathrm{X}$ & - \\
\hline $\mathbf{P b}$ & $\mathrm{X}$ & - & $\mathrm{X}$ & - \\
\hline $\mathbf{H g}$ & $\mathrm{X}$ & $\mathrm{X}$ & $\mathrm{X}$ & - \\
\hline $\mathrm{Se}$ & $\mathrm{X}$ & - & $\mathrm{X}$ & - \\
\hline Ag & $\mathrm{X}$ & - & $\mathrm{X}$ & - \\
\hline Al & $\mathrm{X}$ & - & - & - \\
\hline $\mathrm{Ni}(\mathrm{OH})_{2}$ & $\mathrm{X}$ & $\mathrm{X}$ & - & - \\
\hline TOC & $\mathrm{X}$ & - & - & $\mathrm{X}$ for Trimethylamine \\
\hline TPB & $\mathrm{X}$ & - & - & - \\
\hline $\mathrm{Na}$ & $\mathrm{X}$ & - & - & - \\
\hline Total Insoluble Solids & $\mathrm{X}$ & - & - & - \\
\hline Butanol/Isobutanol & $\mathrm{X}$ & - & - & $\mathrm{X}$ \\
\hline Isopropanol & $\mathrm{X}$ & - & - & - \\
\hline Phenol & $\mathrm{X}$ & - & - & - \\
\hline Methanol & $\mathrm{X}$ & - & - & - \\
\hline TBP & $\mathrm{X}$ & - & - & - \\
\hline Isopar $\mathbf{L}$ & $\mathrm{X}$ & - & - & - \\
\hline NORPAR 13 & $\mathrm{X}$ & - & - & - \\
\hline pH & $\mathrm{X}$ & - & - & - \\
\hline $\mathbf{T i}$ & - & $\mathrm{X}$ & - & - \\
\hline B & $\mathrm{T}$ & - & - & - \\
\hline Co & $\mathrm{T}$ & - & - & - \\
\hline $\mathbf{C u}$ & $\mathrm{T}$ & $\mathrm{X}$ & - & - \\
\hline $\mathrm{Fe}$ & $\mathrm{T}$ & - & - & - \\
\hline $\mathbf{K}$ & $\mathrm{T}$ & - & - & $X$ \\
\hline $\mathbf{L i}$ & $\mathrm{T}$ & - & - & - \\
\hline Mn & $\mathrm{T}$ & $\mathrm{X}$ & - & - \\
\hline Mo & $\mathrm{T}$ & - & - & - \\
\hline $\mathrm{Ni}$ & $\mathrm{T}$ & - & - & - \\
\hline $\mathbf{S i}$ & $\mathrm{T}$ & - & - & - \\
\hline
\end{tabular}

Notes: SW - Solid Waste acceptance criteria 
Table 3-2 (continued) - Required Chemical Constituents for Salt Batch Qualification

\begin{tabular}{|c|c|c|c|c|}
\hline Constituents & Saltstone & DWPF & SW & Tank Farm \\
\hline Sr & $\mathrm{T}$ & - & - & - \\
\hline Zn & $\mathrm{T}$ & - & - & - \\
\hline Benzene & $\mathrm{T}$ & - & - & - \\
\hline Toluene & $\mathrm{T}$ & - & - & - \\
\hline EDTA & $\mathrm{T}$ & - & - & $\mathrm{X}$ \\
\hline P & - & - & - & $\mathrm{X}$ \\
\hline CHO $_{2}$ & - & - & - & - \\
\hline
\end{tabular}

Notes: SW - Solid Waste acceptance criteria. X - indicates the analyses required for batch qualification. $\mathrm{T}$ - indicates the target. 
Table 3-3- Required WAC Analysis for ARP/MCU Qualification

\begin{tabular}{|c|c|c|c|}
\hline Radionuclides & WAC Limit (pCi/mL) & Constituents & WAC Limit \\
\hline H-3 & $5.63 \mathrm{E}+05$ & $\mathrm{NH}_{4}^{+}$ & $2.12 \mathrm{E}+02 \mathrm{mg} / \mathrm{L}$ \\
\hline C-14 & $1.13 \mathrm{E}+05$ & $\mathrm{CO}_{3}{ }^{2-}$ & $1.45 \mathrm{E}+05 \mathrm{mg} / \mathrm{L}$ \\
\hline Ni-63 & $1.13 \mathrm{E}+05$ & $\mathrm{Cl}^{-}$ & $9.68 \mathrm{E}+03 \mathrm{mg} / \mathrm{L}$ \\
\hline Sr-90/Y-90 & $2.25 \mathrm{E}+07$ & $\mathbf{F}^{-}$ & $4.94 \mathrm{E}+03 \mathrm{mg} / \mathrm{L}$ \\
\hline Tc-99 & $4.22 \mathrm{E}+05$ & $\mathbf{O H}^{-}$ & $1.91 \mathrm{E}+05 \mathrm{mg} / \mathrm{L}$ \\
\hline I-129 & $1.13 \mathrm{E}+03$ & $\mathrm{NO}_{3}^{-}$ & $5.29 \mathrm{E}+05 \mathrm{mg} / \mathrm{L}$ \\
\hline Cs-137/Ba-37m & $4.75 \mathrm{E}+07$ & $\mathrm{NO}_{2}^{-}$ & $2.59 \mathrm{E}+05 \mathrm{mg} / \mathrm{L}$ \\
\hline $\mathrm{U}-233$ & $1.13 \mathrm{E}+04$ & $\mathrm{C}_{2} \mathrm{O}_{4}{ }^{2-}$ & $3.30 \mathrm{E}+04 \mathrm{mg} / \mathrm{L}$ \\
\hline U-235 & $1.13 \mathrm{E}+02$ & $\mathrm{PO}_{4}{ }^{3-}$ & $1.90 \mathrm{E}+02 \mathrm{mg} / \mathrm{L}$ \\
\hline Pu-241 & $8.38 \mathrm{E}+05$ & $\mathrm{SO}_{4}{ }^{2-}$ & $6.89 \mathrm{E}+04 \mathrm{mg} / \mathrm{L}$ \\
\hline Total Alpha & $2.50 \mathrm{E}+05$ & As & $7.50 \mathrm{E}+02 \mathrm{mg} / \mathrm{L}$ \\
\hline Total Gamma & $4.75 \mathrm{E}+07$ & $\mathbf{B a}$ & $7.50 \mathrm{E}+02 \mathrm{mg} / \mathrm{L}$ \\
\hline Co-60 & $1.13 \mathrm{E}+06$ & $\mathbf{C d}$ & $3.75 \mathrm{E}+02 \mathrm{mg} / \mathrm{L}$ \\
\hline Ni-59 & $1.13 \mathrm{E}+05$ & $\mathrm{Cr}$ & $1.50 \mathrm{E}+03 \mathrm{mg} / \mathrm{L}$ \\
\hline Nb-94 & $1.53 \mathrm{E}+04$ & $\mathbf{P b}$ & $7.50 \mathrm{E}+02 \mathrm{mg} / \mathrm{L}$ \\
\hline Ru-106/Rh-106 & $1.13 \mathrm{E}+06$ & $\mathbf{H g}$ & $3.25 \mathrm{E}+02 \mathrm{mg} / \mathrm{L}$ \\
\hline Sb-125 & $2.25 \mathrm{E}+06$ & Se & $4.50 \mathrm{E}+02 \mathrm{mg} / \mathrm{L}$ \\
\hline Sn-126 & $1.80 \mathrm{E}+04$ & Ag & $7.50 \mathrm{E}+02 \mathrm{mg} / \mathrm{L}$ \\
\hline Cs-134 & $1.13 \mathrm{E}+06$ & Al & $1.41 \mathrm{E}+05 \mathrm{mg} / \mathrm{L}$ \\
\hline Cs-135 & $1.13 \mathrm{E}+06$ & TOC & $5.90 \mathrm{E}+02 \mathrm{mg} / \mathrm{L}$ \\
\hline Ce-144/Pr-144 & $1.13 \mathrm{E}+05$ & TPB & $5.00 \mathrm{E}+00 \mathrm{mg} / \mathrm{L}$ \\
\hline Pm-147 & $5.63 \mathrm{E}+06$ & $\mathrm{Na}^{+}$ & $2.5 \mathrm{M}<\left[\mathrm{Na}^{+}\right]<7.0 \mathrm{M}$ \\
\hline Sm-151 & $2.25 \mathrm{E}+04$ & Total Insoluble Solids & $<1.88 \mathrm{E}+05$ mg/L (15 wt. \%) \\
\hline Eu-154 & $2.25 \mathrm{E}+06$ & Butanol/Isobutanol & $0.75 \mathrm{mg} / \mathrm{L}$ \\
\hline Eu-155 & $1.13 \mathrm{E}+04$ & Isopropanol & $0.25 \mathrm{mg} / \mathrm{L}$ \\
\hline $\operatorname{Ra}-226(\alpha)$ & $7.97 \mathrm{E}+03$ & Phenol & $7.50 \mathrm{E}+02 \mathrm{mg} / \mathrm{L}$ \\
\hline $\mathrm{U}-232(\alpha)$ & $1.71 \mathrm{E}+05$ & Methanol & $0.25 \mathrm{mg} / \mathrm{L}$ \\
\hline 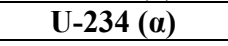 & $1.13 \mathrm{E}+04$ & TBP & $1.0 \mathrm{mg} / \mathrm{L}$ \\
\hline $\mathrm{U}-236(\alpha)$ & $1.13 \mathrm{E}+04$ & pH & $\mathrm{pH}>10$ \\
\hline U-238 & $1.13 \mathrm{E}+04$ & $\mathbf{T i}$ & $* *$ \\
\hline $\mathrm{Np}-237(\alpha)$ & $2.50 \mathrm{E}+05$ & $\mathbf{C u}$ & $9.00 \mathrm{E}+02 \mathrm{mg} / \mathrm{L}$ \\
\hline Pu-238 sol/total & $7.93 \mathrm{E}+05 / 2.50 \mathrm{E}+05$ & Mn & $9.00 \mathrm{E}+02 \mathrm{mg} / \mathrm{L}$ \\
\hline Pu-239 & $3.86 \mathrm{E}+04$ & $\mathbf{K}$ & $1.95 \mathrm{E}+03 \mathrm{mg} / \mathrm{L}$ \\
\hline Pu-240 & $1.86 \mathrm{E}+04$ & $\mathrm{CHO}_{2}$ & $4.50 \mathrm{E}+03 \mathrm{mg} / \mathrm{L}$ \\
\hline Pu-242 & $2.50 \mathrm{E}+05$ & $\mathbf{P}$ & $4.18 \mathrm{E}+02 \mathrm{mg} / \mathrm{L}$ \\
\hline Pu-244 & $7.02 \mathrm{E}+04$ & Total Soluble Pu & $0.1 \mathrm{mg} / \mathrm{L}$ \\
\hline Am-241 & $2.50 \mathrm{E}+05$ & Total Soluble U & $50 \mathrm{mg} / \mathrm{L}$ \\
\hline Am-243 & $2.50 \mathrm{E}+05$ & $\mathrm{Ni}(\mathrm{OH})_{2}$ & $3.95 \mathrm{E}+03 \mathrm{mg} / \mathrm{L}$ \\
\hline Cm-244 & $1.86 \mathrm{E}+05$ & & \\
\hline Cm-245 & $2.25 \mathrm{E}+05$ & \multicolumn{2}{|c|}{$\begin{array}{l}\text { *Limit is } 260 \mathrm{mg} / \mathrm{kg} \text { Land Disposal Regulation (LDR) limit, } \\
\text { WAC Limit of } 325 \mathrm{mg} / \mathrm{L} \text { assumes density of } 1.25 \mathrm{~g} / \mathrm{mL}\end{array}$} \\
\hline Total Beta & $* *$ & \multicolumn{2}{|c|}{ ** Detection limit should be as low as practically achievable } \\
\hline
\end{tabular}


SRNL-STI-2011-00723

Revision 0

Table 3-4 - Nuclides Requiring Lower Detection Limits Post-Qualification Analyses

\begin{tabular}{|c|c|}
\hline Radionuclide & Detection Limit (pCi/mL) \\
\hline${ }^{\mathbf{5 9}} \mathbf{N i}$ & $2.00 \mathrm{E}+01^{*}$ \\
\hline${ }^{\mathbf{9 4}} \mathbf{N b}$ & $4.38 \mathrm{E}-01^{*}$ \\
\hline${ }^{135} \mathbf{C s}$ & $* *$ \\
\hline${ }^{144} \mathbf{C e} /{ }^{144} \mathbf{P r}$ & $1.03 \mathrm{E}+01^{*}$ \\
\hline${ }^{226} \mathbf{R a}$ & $4.08 \mathrm{E}+01^{*}$ \\
\hline${ }^{232} \mathbf{U}$ & $* *$ \\
\hline${ }^{233} \mathbf{U}$ & $* *$ \\
\hline${ }^{243} \mathbf{A m}$ & $* *$ \\
\hline${ }^{244} \mathbf{P u}$ & $* * *$ \\
\hline${ }^{245} \mathbf{C m}$ & $* * *$ \\
\hline${ }^{251} \mathbf{C f}$ & $9.01 \mathrm{E}+01^{*}$ \\
\hline
\end{tabular}

*Achievable per SRNL-L4000-2009-00028.

**Measured above detection limits for Tank $50 \mathrm{H}$. Use normal Tank $50 \mathrm{H}$ methods.

***Detection limit should be as low as practically achievable.

\subsection{DWPF/HLW Qualification}

The DWPF's mission is to immobilize HLW consisting of two fractions. The sludge fraction is comprised of the insoluble solids containing the long-lived radionuclides and inert components such as iron and aluminum hydroxide, and the salt fraction containing Cs, actinides, and sludge solids that have been treated through salt waste processing facilities. Before the sludge and salt streams can be treated in the DWPF, several process steps must be performed to prepare the streams for treatment. The pretreatment for the salt streams is described in the preceding sections. The sludge stream must be transferred into the DWPF sludge preparation tank (Tank 51) to undergo Extended Sludge Processing (ESP) - refer to Figure 3-1.

\subsubsection{Extended Sludge Processing}

Typically, sludge from more than one tank is transferred to the preparation tank to provide a blended sludge composition suitable for DWPF processing. The tanks being blended are selected by SRR based on necessary tank closure dates and expected sludge compositions. ESP is initiated with the introduction of inhibited water (water with dilute concentrations of sodium hydroxide and sodium nitrite) or by decanting of supernate to reduce the high sodium salt content of the sludge. The iterative process is repeated until the final sodium supernate concentration target and the insoluble/total solids target are obtained. The final product constitutes a sludge batch for DWPF.

To ensure that the blended tanks will produce an acceptable glass, SRR uses information available in their Waste Characterization System (WCS) to project the sludge composition taking into account washing and/or Al dissolution. Models are used to predict glass process and product quality properties based on the blends of this projected sludge composition with known frits at the required waste loadings to ensure that the resulting glass formulation will meet the DWPF processing and acceptability criteria. Further optimization of the washing endpoint and frit composition is performed by SRNL as part of the qualification process and this information is fed back to SRR for use by their planning group. 
Once all of the sludge has been transferred to the feed preparation tank, a qualification sample is pulled and shipped to the SRNL for commencement of qualification activities. At this point, no additional transfers can occur to the feed preparation tank unless a representative sample of the material is taken and appropriately blended with the qualification sample in SRNL so it can be included as part of the qualification process. The latter typically occurs when a Pu disposition stream is added to the batch since it sometimes is not ready for transfer until after the qualification sample is taken. It is a relatively small volume stream that contains minor elemental species but its anion concentration can impact the sludge anion composition so it is added to the qualification sample. An initial chemical characterization and limited physical property determination are performed on the sample. This information is fed back to the SRR planning group to update their washing and preparation plans.

Depending on when the qualification sample is taken, multiple wash and decant cycles may need to be performed by SRNL in the Shielded Cells to complete the sludge batch preparation process. After the first couple of sludge batch qualifications, SRNL recommended individual replication of these cycles instead of one large wash to obtain the endpoint to allow identification of potential problems with sludge settling and to verify the accuracy of washing model predictions. As this washing is being performed, SRNL continues to evaluate the washing endpoint through flowsheet testing and glass formulation assessments to minimize the amount of washing required in the tank farm while ensuring process flexibility. An additional key consideration in this step is the sludge rheology, which can be dramatically impacted by washing and the final insoluble solids concentration. This combined information is used by SRNL to recommend the final washing endpoint (including sodium and anion concentrations and target insoluble solids). Based on SRNL's experience to date, these endpoints may change from batch to batch especially as more information is gained on the behavior of sludge components during DWPF processing but the process for reaching the endpoint has been consistent.

Once the qualification sample has reached the final endpoint, extensive chemical and radionuclide characterization is performed and the physical properties are measured. This information is used by DWPF to meet their waste compliance and safety basis requirements. To ensure that the material qualified by SRNL is representative of the sludge to be transferred to DWPF, the Tank Farm takes an additional smaller confirmation sample near the end of their ESP activities to verify the composition. This allows any adjustments to be made should the results not match or bound those of the qualification sample.

\subsubsection{Al Dissolution}

Aluminum dissolution has only been performed on two recent batches for DWPF processing. In both of these cases, the Al dissolution step was performed outside of the typical DWPF sludge batch qualification process. At SRS, the Al dissolution has been performed in the tank farm by adding concentrated caustic, heating to between 55 and $65^{\circ} \mathrm{C}$, mixing for extended periods ( 28 days), and then decanting the dissolved $\mathrm{Al}$ containing supernate. Chemical models are used to determine the required caustic concentration and contact time to meet the $\mathrm{Al}$ removal targets for acceptable glass production. These models have been verified with actual Al dissolution demonstrations in the SRNL Shielded Cells. Although SRNL testing has been performed on $<3$ $\mathrm{L}$ of sample, the results have been fairly consistent with actual plant results.

At this point, SRNL has not been able to define a representative simulant for performing $\mathrm{Al}$ dissolution. However, SRNL has been successful at defining a small-scale beaker test to determine whether the $\mathrm{Al}$ in the sludge behaves more like the boehmite or gibbsite phase. This information can be used to define operating parameters based on the models in a shorter time span than the full demonstration of the Al dissolution process. 


\subsubsection{DWPF Flowsheet Testing}

During the early days of the development of the DWPF processing flowsheet, a wide range of sludge simulant compositions were tested spanning the expected range of sludge compositions, and perhaps more importantly, spanning the range of expected troublesome components to be processed in the DWPF. These tests helped define nominal operational parameters for the Chemical Process Cell (CPC), where a combination of nitric and formic acids is added at $93^{\circ} \mathrm{C}$ to initiate the necessary chemical reactions including the reduction of $\mathrm{Hg}$. In addition, the sludge is heated to boiling, where concentration and reflux occur, to complete the reactions and strip the Hg. These steps are performed in the Sludge Receipt and Adjustment Tank (SRAT) in DWPF, and then the slurry is transferred to the Slurry Mix Evaporator (SME) tank. In the SME, frit is added at the targeted waste loading and the slurry is boiled further to the melter feed solids target, which is typically in the range of $45-50$ weight percent total solids.

Based on the early tests, the operating parameters for DWPF were set with the primary variable to be defined from batch to batch being the amounts and ratio of acid to add. This is the piece of information that is verified in the qualification runs with the recommended amount being enough to complete the necessary reactions but not so much that excessive catalytic hydrogen is generated. Other process parameters that are defined include determining the time required for $\mathrm{Hg}$ stripping, the amount of antifoam to add, and the solids endpoint from a rheological standpoint for each process in the flowsheet. Simulant tests are used to refine these parameters, and a flowsheet test is performed at the recommended conditions with the radioactive qualification sample.

Early in the qualification process, SRNL receives sludge composition projection information to allow fabrication of simulants for DWPF flowsheet testing. If the composition is significantly different than material already processed through the DWPF, then a recipe for fabricating the new simulant is prepared. The simulant is made to represent the final washed sludge. Washing is performed on the simulant but only to allow the final composition to be matched and not to replicate the in-tank washing performed by SRR. This simulant is used to perform a series of flowsheet tests to define the acid operating window for DWPF for that particular sludge batch. Based on the collected data (e.g., hydrogen generation, Hg stripping, and rheology), SRNL selects a nominal acid addition strategy for the radioactive qualification test and for DWPF processing.

When the DWPF started up, the salt waste processing facilities had not been brought on-line and the processes/flowsheets were subsequently changed. The high activity and solids containing fractions of the effluent from the salt processing facilities have to be processed through the DWPF CPC. The MST/sludge solids stream is added to the SRAT at boiling before the initiation of the SRAT process (i.e., before acid addition). After the stream is added, a sample is taken to determine the acid addition amounts and then typical processing is initiated.

The MST/sludge solids stream itself has been shown, through simulant flowsheet testing with bounding volumes of the stream, to have minimal impact on the SRAT processing chemistry, but the stream does increase the SRAT processing time because of the additional boiling required. Due to the large volume of salt sample and associated radioactive dose that would be required to perform a demonstration of the coupled process, qualification for DWPF is not performed on radioactive material as is done with the sludge. Qualification of the MST/sludge solids stream for DWPF processing was performed by SRNL using simulants in flowsheet testing prior to ARP/MCU incorporation and is now only verified with a simulant run as part of the simulant flowsheet testing. This strategy was possible after demonstrations with bounding levels showed 
minimal impact from the primary constituents and because the low concentrations of radioactive constituents are not believed to have a significant impact on processing characteristics. Once again, this stream is not tested with the qualification sample as part of the sludge batch preparation process, but, as described above, the constituents in the salt streams that are fed to the DWPF are considered in the data reporting for the overall waste compliance.

The strip effluent from the MCU process, and when it comes online, from the SWPF, is transferred to the DWPF in small batches. These batches are held in a hold tank until they can be transferred to the SRAT during the boiling process after all acid has been added. The stream is a dilute nitric acid stream that contains low concentrations of the removed cesium and nonrecovered solvent; thus, the stream has the potential to impact the feed redox because of the nitrate in the stream. The cesium has no impact on the CPC flowsheet, while the residual solvent results in flammability concerns for DWPF. Flammability is primarily controlled by the addition at boiling and insurance of purge gas during static and processing conditions. This has a net impact on the SRAT processing time. As with the MST/sludge solids stream, qualification is only performed using simulant streams, which are considered adequate to bound the potential processing impacts. This was possible after sufficient flowsheet testing with simulants was performed to demonstrate that minimal impact would be realized on the flowsheet.

\subsubsection{Glass Formulation Testing}

There are two primary studies that are currently used to qualify a sludge batch for DWPF with respect to the glass waste form: (1) a compositional variability study and (2) fabrication of the qualification glass in the SRNL Shielded Cells facility. A brief discussion of each of these studies is provided below.

\subsubsection{Variability Study}

Similar to the WTP qualification approach for both LAW and HLW glass, the DWPF glass algorithms (referred to as the Product Composition Control System (PCCS)) ${ }^{8}$ play an integral role in the qualification process. PCCS is a collection of models that are used to predict various process (e.g., viscosity and liquids temperature) as well as product performance (i.e., durability as defined by the Product Consistency Test (PCT) $)^{9}$ properties of glass. The durability models embedded in PCCS are used to predict the PCT response based on glass composition (target or measured). The objective of the variability study during sludge batch qualification is two-fold: (1) to demonstrate that the durability models are applicable to the glass system to be processed through DWPF and (2) to demonstrate that the durabilities of the glasses are acceptable relative to the durability of the benchmark Environmental Assessment (EA) glass. ${ }^{10}$ Demonstrating that the models are applicable to the glass compositional region is critical given PCCS is used to assess the acceptability of melter feed during DWPF operations. That is, once the frit has been blended with sludge in the SME and samples are taken, vitrified, and compositionally measured using ICP-AES, then the compositional analysis is used as input into PCCS to predict the critical process and product performance properties, and those predictions are compared to pre-defined acceptance criteria. If all of the predictions simultaneously satisfy their respective constraints, the melter feed is transferred to the Melter Feed Tank (MFT) and ultimately to the melter. If not, decisions regarding remediation of the SME batch are made prior to a subsequent re-qualification effort for the SME before transferring its contents to the melter feed tank. In this "feed forward" process control strategy, ensuring the models embedded within PCCS are applicable to the glass composition region being processed is critical - especially with respect to durability. As previously mentioned, this is the objective of the variability study which is performed prior to transferring a new sludge batch to DWPF. 
Prior to specifically discussing the experimental approach to the variability study, one must first understand how the glass compositional region of interest is defined for each sludge batch. The glass compositional region is defined by three factors: (1) sludge composition, (2) frit composition, and (3) the waste loading interval of interest. The sludge composition is provided through analysis of the qualification sample received from SRR as discussed in Section 3.3.1. Prior to implementation of the variability study, SRNL also recommends the specific frit composition to be used to process each sludge batch. The frit recommendation process relies heavily on PCCS for which specific glass compositions based on various frit-sludge combinations over a range of waste loadings can be mathematically computed and from which projected operating windows can be defined. A projected operating window for a sludge-frit system is defined as the waste loading interval over which all glass properties are classified as acceptable. Knowing the sludge composition, frit composition, and the anticipated waste loading interval over which DWPF could process, SRNL can define a glass region of interest. It is important to note that although the nominal composition of the sludge is provided, DWPF will ultimately not receive the "exact" composition upon each transfer into the SRAT. Uncertainties associated with sludge transfers, sampling, and compositional analysis are anticipated and built into the development of the glass compositional region to be evaluated during frit selection and through the variability study.

Once the glass compositional region is defined, glasses are selected within that multi-dimensional compositional space to allow for an assessment of the applicability of the durability models. Statistical algorithms are used in the glass selection process to provide appropriate coverage of the glass region of interest. These glasses are typically supplemented by a series of nominal glass compositions over a series of waste loadings. The process typically results in $20-30$ glasses. A key point for this study is that the glasses are ultimately made using reagent grade chemicals to target the matrix of glasses identified. That is, these glasses are not based on use of the actual radioactive qualification sample - although the variability study glasses do include $\mathrm{U}_{3} \mathrm{O}_{8}$ and $\mathrm{ThO}_{2}$. The fundamental basis for this approach is that the oxides less than $0.5 \mathrm{wt} \%$ in glass will have no significant impact on the durability response (assuming all other process related criteria are met). Glasses are then fabricated in the laboratory, their compositions measured by ICP-AES analysis after appropriate digestions/fusions to ensure targeted compositions were met, and the durability (as defined by the PCT) is measured for each glass (using two thermal heat treatments $^{\text {iv }}$ ). Based on the measured PCT response and the compositional analysis, assessments are made as to whether the durability models within PCCS are applicable to the compositional region of interest for the specific frit-sludge region as well as to ensure the durabilities of glasses are acceptable relative to that of the EA benchmark glass.

The results of the study provide the technical basis for demonstrating that the models to be used for SME acceptability decisions are applicable to the glass system being processed. Again, the variability study is completed prior to the transfer of sludge to DWPF.

\subsubsection{Qualification Glass: Shielded Cells Testing}

In addition to the glass variability study, a second process is currently used to qualify a sludge batch from a glass formulation perspective. As discussed in Section 3.3.1, the qualification sample from the tank farm is used to provide compositional information to support blending assessments as well as to support flowsheet development activities (more specifically

\footnotetext{
iv Two thermal heat treatments are used to capture the possible impact of kinetics on the formation of crystal phases that could have an impact on the durability response. These heat treatments are referred to as quenched (a rapidly cooled glass from the nominal $1150{ }^{\circ} \mathrm{C}$ melt temperature) and centerline canister cooled (simulating the worst case thermal history a glass would experience, which was along the centerline of a DWPF type canister).
} 
SRAT/SME process related issues associated with hydrogen generation, acid addition strategies, and rheology for feed transfer). After the SME process, a portion of the frit-sludge mixture is used to fabricate a glass product. The SME product is transferred to a Pt-alloy crucible and vitrified in a resistance furnace in the SRNL Shielded Cells to produce a glass waste form. This process is comparable to the WTP approach to be discussed in Section 4.9. In fact, the composition of the glass is also measured (via ICP-AES and -MS following digestion/fusion of the glass) and the analytical results are used to predict the properties of the glass. This is again consistent with the WTP approach presented during the workshop. However, one difference between the two approaches is that SRNL also experimentally measures the durability of the glass and compares the measured response to model predictions. Although this is a single data point (specific frit, "constant” sludge, at a fixed waste loading), it provides additional confidence that the glass to be processed in DWPF would not only be acceptable but that the PCCS models are applicable. This in conjunction with the variability study form the basis of the qualification activities associated with DWPF's glass waste form.

\subsection{Saltstone}

Tank 50 (see Figure 3-1) provides the feed to the Saltstone Production Facility (SPF). Presently the primary feeds to Tank 50 come from the effluent treatment project (ETP), H canyon discharge, salt solutions from the HLW storage tanks and the decontaminated salt solution from the ARP/MCU facility. In the future, decontaminated salt solution from SWPF will replace ARP/MCU. These streams must comply with the WAC requirements for SPF. ${ }^{5}$ Samples are pulled from Tank 50 and analyzed based on the Saltstone WAC requirements. The sample size, frequency, requirements and basis for the sample needs are provided in Table 3-5. The grout wasteform in Table 3-5 are the Tank 50 waste stream blended with a combination of Portland cement, slag, and carbon burnout fly ash called premix (and is considered cementitious material). Concrete admixtures may be added to make the blend of waste and premix meet the SPF processing requirements. Samples are provided to SRNL for the various assessments specified in the WAC and SRNL also prepares the grout for offsite TCLP analysis. At the SPF, the premix and waste are blended in a mixer, fed to a hopper, and pumped into Saltstone disposal vaults where the grout solidifies into a monolithic, non-hazardous, solid LLW form. 
SRNL-STI-2011-00723

Revision 0

Table 3-5 Tank 50 Samples Needed for Saltstone

\begin{tabular}{|c|c|c|c|c|}
\hline $\begin{array}{l}\text { Sample Size } \\
\text { (Projected) }\end{array}$ & Frequency & Requirement & $\begin{array}{l}\text { Sample } \\
\text { Size }\end{array}$ & Basis \\
\hline \multirow{3}{*}{4.4 liters } & \multirow{3}{*}{$\begin{array}{c}\text { Vault } \\
\text { classification } \\
\text { or New } \\
\text { Waste Stream }\end{array}$} & $\begin{array}{c}\text { Vault } \\
\text { Classification }\end{array}$ & 1 liter & $\begin{array}{l}\text { Required every } 5 \text { years and for the } \\
\text { New Waste Stream Permit. } \\
\text { Evaluates the landfill requirements } \\
\text { and effects on groundwater. }\end{array}$ \\
\hline & & Initial TCLP & $500 \mathrm{ml}$ & $\begin{array}{l}\text { Initial verification of non-hazardous } \\
\text { nature of grout }\end{array}$ \\
\hline & & $\begin{array}{l}\text { Initial grout } \\
\text { formulation }\end{array}$ & 2.9 liters & $\begin{array}{l}\text { Initial verification that the grout will } \\
\text { meet the processing requirements }\end{array}$ \\
\hline 2 liters & $\begin{array}{l}\text { Each Salt } \\
\text { Batch (as } \\
\text { required) }\end{array}$ & $\begin{array}{l}\text { Grout } \\
\text { Formulation }\end{array}$ & 2 liters & $\begin{array}{l}\text { Verification that the grout will meet } \\
\text { the processing requirements }\end{array}$ \\
\hline \multirow[t]{2}{*}{$850 \mathrm{ml}$} & \multirow[t]{2}{*}{$\begin{array}{l}\text { Quarterly or } \\
\text { each Salt } \\
\text { Batch }\end{array}$} & $\begin{array}{l}\text { Regulatory } \\
\text { compliance - } \\
\text { Liquid chemistry }\end{array}$ & $350 \mathrm{ml}$ & $\begin{array}{l}\text { Compliance of liquid chemistry with } \\
\text { permit tables. Used in material } \\
\text { balance for quarterly reports to } \\
\text { SCDHEC. } 200 \mathrm{ml} \text { of the } 350 \mathrm{ml} \\
\text { needed for organic analysis }\end{array}$ \\
\hline & & Offsite TCLP & $500 \mathrm{ml}$ & $\begin{array}{l}\text { Verification of non-hazardous nature } \\
\text { of grout by EPA certified laboratory }\end{array}$ \\
\hline $500 \mathrm{ml}$ & $\begin{array}{l}\text { Semi- } \\
\text { Annually or } \\
\text { each salt } \\
\text { batch }\end{array}$ & $\begin{array}{l}\text { Regulatory } \\
\text { compliance - } \\
\text { liquid } \\
\text { radiological }\end{array}$ & $500 \mathrm{ml}$ & $\begin{array}{l}\text { Compliance of liquid radionuclides } \\
\text { with permit tables. Used in material } \\
\text { balance for quarterly reports to } \\
\text { SCDHEC. }\end{array}$ \\
\hline
\end{tabular}

\subsection{Lessons Learned}

Since the start-up of the DWPF, several lessons have been learned and process changes have been implemented with potential applicability to WTP. An enumerated list is provided with a brief description of the impact.

1. Pour Stream Sample Characterization - Several pour stream samples were pulled during processing of Sludge Batch 1a for DWPF to demonstrate applicability of the waste qualification strategy (i.e., models were actually predicting performance and glass composition). The number of samples has been reduced to two per batch, with one subjected to characterization and the other archived. SRR is undertaking an effort to eliminate the characterization effort based on successful demonstration of the waste compliance strategy over several batches since start-up.

2. Waste Loading - Baseline sludge waste loading was $28 \%$ at start-up. Improvements have been made in the glass property models and in understanding the behavior of the radioactive slurry and melter operations to allow significant increases in waste loading, up to $38 \%$. The optimal waste loading for processing has changed with each sludge batch.

3. Washing Endpoint - At start-up, the washing endpoint correlated to $0.5 \mathrm{M} \mathrm{Na}$. This was believed to be optimal for melter feed preparation (chemical processing) and wasteform durability. Improvements in the understanding of the feed preparation chemistry and glass product models have allowed the $\mathrm{Na}$ target endpoint to be increased (up to approximately 1.2 M Na) after the third sludge batch was processed in DWPF. A benefit was also seen for the rheology of the sludge post washing at these higher $\mathrm{Na}$ 
concentrations and glass formulations adjusted to ensure product performance were not compromised. Another reason why a significant shift in the washing strategy was possible was the ability to increase the sulfate retention or solubility in glass through strategic frit development efforts. In general, less washing typically leaves more sulfate that must be accommodated by the glass.

4. Frit composition - When the DWPF processing strategy was being developed, a frit composition that allowed processing (at lower waste loadings) for all sludge batches was selected. The frit was not optimized for any particular waste but ensured all could be processed within DWPF's processing window. Since start-up, SRNL has been able to show a clear advantage to tailoring the frit to the particular sludge batch and adjustments have directly allowed for the changes in washing endpoint. This may not be directly applicable to WTP since glass forming materials will be used but it does highlight the importance of being able to adjust the ratios of the additives and for remaining flexible upon start-up.

5. Troublesome components - Every batch has had a new component or increased concentration of a troublesome component to make each batch slightly different from the last one from a processing perspective. In some cases, these components have been found in the feed and were unexpected. While in other cases, the increased concentrations resulted from additions of secondary or excess streams that had to be performed to meet DNFSB commitments for stabilization of nuclear materials. ${ }^{v}$ Maintaining core R\&D funds and resources have allowed DWPF to accommodate these unknowns.

6. Impacts of heels - The DWPF chemical processing flowsheet was designed to accommodate heels in the DWPF process vessels. However, the Tank Farm feed tanks were originally assumed to be fed to a very low level that the heel would have minimal impact on the previous compositions. When acceleration of waste throughput was pursued, this changed the strategy for how batches were prepared and staged for DWPF processing. With one tank permanently preparing the batch (Tank 51) and the other continuously feeding DWPF (Tank 40), the impact of the heel volumes always needs to be considered because of the potential changes to the overall sludge composition to be processed. There have been some batches where more sludge remained in the feed tank than what was transferred for the newly qualified batch. This requires adjustment of the qualification strategy to ensure that what will be processed in the DWPF is understood.

7. Al dissolution - Original planning for DWPF operations assumed some amount of Al dissolution would be performed to accommodate high Al sludges. About the time that DWPF was started up, Al dissolution was abandoned due to facility modifications that would be required in the Tank Farm with higher temperature dissolution. After preparing Sludge Batch 4, the Liquid Waste contractor decided to pursue lower temperature $\mathrm{Al}$ dissolution $\left(55-70^{\circ} \mathrm{C}\right)$ to minimize the number of canisters being produced. Limited testing was performed on the potential downstream impacts of the process because the SRR contractor felt that the impacts were properly understood because it used to be the baseline process. Some negative impacts believed to be associated with Al dissolution were discovered in processing and included sludge with a higher yield stress, more tackiness and an affinity for foaming during SRAT processing. Another unintended consequence was longer SRAT processing times because of the higher concentration of $\mathrm{Hg}$ in the slurry (requiring longer process stripping times) and potentially lower melter

\footnotetext{
${ }^{v}$ Secondary or excess streams such as $\mathrm{Pu}, \mathrm{Np}$, Am, and/or $\mathrm{Cm}$ from canyon operations or storage are sometimes introduced into the DWPF flowsheet as a means of immobilizing these components. These secondary or auxiliary streams are not recycle streams from the DWPF flowsheet (e.g., melter off-gas or carry-over). The streams are typically introduced into the Tank Farm and the washing and qualification strategy must account for them.
} 
throughput rates (waste loading was limited to 34\% for the first $\mathrm{Al}$ dissolved batch). These processing issues had to be accommodated by the plant during processing. When this occurs, the options to improve processing are limited because the batch has already been prepared and qualified.

\subsection{WTP Specific Unit Operations: An SRNL Perspective of Workshop Discussions}

In Section 2.0, a general overview of the WTP waste qualification program from SRNL's perspective was presented. Based on the workshop discussions, the intent of the waste qualification testing is to demonstrate compliance with waste acceptance criteria, evaluate waste processability, and demonstrate laboratory-scale unit operations. SRNL has completed a critical review of the WAC-DQO parameters in support of qualification and that study is documented elsewhere. ${ }^{2}$ The major unit operations discussed at the workshop included:

$\begin{array}{ll}\text { o } & \text { Mixing / Sampling } \\ \text { o } & \text { Sludge washing leaching } \\ \text { o } & \text { Ion Exchange } \\ \text { o } & \text { Cross flow ultrafiltration } \\ \text { o } & \text { Boil down } \\ \text { o } & \text { Foaming } \\ \text { o } & \text { Hydrogen generation rates } \\ \text { o } & \text { Wear/Abrasion/Particle Hardness } \\ \text { o } & \text { Glass Formulation }\end{array}$

In this section, SRNL provides additional thoughts on each specific unit operation as to its objective and its informational needs during the qualification process. That is, what data or information is intended to be generated during each unit operation.

\subsection{Mixing / Sampling}

Although not considered a unit operation, mixing/sampling will be important to the successful operation of the WTP in two general areas: 1) Transfer from the Tank Farm to Pretreatment and 2) Between unit operations in the Pretreatment and Vitrification facilities. During the workshop, a TOC representative presented information on waste retrieval, mixing, and sampling. From the discussions generated during the workshop, there did appear to be differences in opinion on what was required for a representative sample for the waste qualification testing. While the TOC is ultimately responsible for providing this representative sample, it has been SRNL's experience that the receiving facility also set acceptance specifications that would help define what representative means to ensure facility operational success.

Additional time was spent throughout the meeting discussing the importance of thorough mixing during the performance of the unit operations. The extent of mixing required will depend on the unit operation since physical properties and waste type can change throughout the facilities. Qualification testing should ensure that the inputs and products to the unit operations will be within the defined bounds for the mixing equipment. With respect to sampling, some streams will be more challenging for obtaining a representative sample and protocols will need to be 
implemented (that may vary across the unit operations) to ensure that campaign decisions are made with necessary and accurate data.

\subsection{Sludge Washing Leaching}

Removal of aluminum by caustic leaching will be required by a significant percentage of the waste campaigns for WTP. Oxidative leaching will be required for a much smaller subset of waste campaigns. In accordance with Contract Specification 12, ${ }^{11}$ assessments will be performed to predict the quantity of immobilized high-level waste product and immobilized low-activity waste product produced as a result of (1) solids washing; (2) caustic leaching and washing; and (3) either (1) or (2) combined with oxidative leaching and washing. Based on the sludge washing-leaching assessments, experiments will be conducted to determine the process conditions. Other data that may need to be generated as part of this unit operation is the potential solubility of $\mathrm{Pu}$ and $\mathrm{U}$ during $\mathrm{Al}$ and $\mathrm{Cr}$ dissolutions and the necessary Na concentration to ensure that dissolved $\mathrm{Al}$ does not precipitate or impact LAW glass formulations.

Although $\mathrm{Al}$ dissolution and $\mathrm{Cr}$ leaching will be performed in the ultrafiltration feed vessels in the WTP-PT facility, the potential for performing these steps outside of the lab-scale Cell Unit Filter (CUF) was discussed in the meeting if it was advantageous to the qualification process. Regardless of the actual location for performing this step during qualification, the parameters will have to be translated into WTP-PT operational parameters.

\subsection{Cross-flow Ultrafiltration}

The full-scale solid-liquid separation process to be employed in the WTP is cross-flow ultrafiltration, which is referred to as the ultrafiltration process system (or UFP). The UFP utilizes a tube and shell configuration where the concentrated waste slurry is pumped through the filter element. A pressure is applied and liquid permeated is collected in the shell of the filter element. This full-scale process is simulated in a CUF configuration which typically employs one two-foot filter element. The qualification program will supply $2-4 \mathrm{~L}$ of feed for the CUF testing and the targeted end point for solids loading is approximately $20 \mathrm{wt} \%$. The filtration testing will be interrupted at various points to allow for the study of the slurry physical properties including rheology, weight percent solids and specific analytical characterization. SRNL reported that the site experience does not support scaling of filter performance from CUF to plant scale..

\subsection{Ion Exchange}

Cesium ion exchange testing will be performed on each qualification sample by the selected laboratory. Documentation indicates that column experiments will be performed to demonstrate the removal efficiency. This poses some problems in that for many of the batches large volumes of tank samples will be required to show the requisite performance. In other words, it will be prohibitive to demonstrate cesium decontamination to $50 \%$ breakthrough on even a small laboratory column. At Savannah River, simple batch tests along with stringent procurement specifications are sufficient to qualify a batch for processing. Planning for processing utilizes the developed ion exchange basis found in the cesium isotherm model and associated experimentation.

Another aspect of ion exchange testing is to examine spent resin characteristics for TRU, Cs-137, Tc-99 and the RCRA metal chromium. The spent resin should be dried and analyzed for radiological content to support determining the spent resin disposal path in the PT facility. 


\subsection{Waste Concentration}

There are three locations in the pretreatment process where evaporation (or waste concentration) is likely to be used. This includes the waste feed evaporator (FEP-SEP-01A/B), the nitric acid recovery evaporator (CNP-EVAP-01) and the treated LAW evaporator (TLP-SEP-01). With the exception of the nitric acid evaporator, the other two unit operations will likely fall within the Qualification Program. In each case, a known volume of waste will be evaporated in a boil-down test rig similar to that used in the testing supporting the 242-A evaporator campaigns. The selected laboratory for the waste feed qualification will measure sodium concentration, density and rheology as a function of percent concentrated. It is assumed that for each of the boil-down tests that the experiment will evaporate the waste past the targeted end point to assess feed stability.

\subsection{Foaming/Antifoam Testing}

Foaming has been seen in previous testing of the Hanford unit operations and nominal addition volumes have been identified. The goal of the qualification assessment is to determine if this quantify is sufficient or if additional amounts of antifoam are necessary for the various unit operations. The starting point for testing will be the baseline dose rate and antifoam composition. The capability to monitor foaming and to add antifoam will have to be integrated across the unit operations testing. During the technical exchange discussions, SRNL conveyed their concerns for ensuring an effective strategy after recent problems with excess antifoam addition in the DWPF. If too much antifoam is added, it can have potential downstream impacts such as melter flammability risks or other processing issues or it may also prove counter-active to the goal at hand (i.e., result in more foaming).

\subsection{Hydrogen Generation Rates}

The generation of radiolytic hydrogen from both LAW and HLW is an important parameter to understand from a nuclear safety standpoint. Currently, the WTP will be required to measure the hydrogen generation rate on the qualification sample as part of the qualification program. However, a reliable method has not been defined. Based on SRNL's experience, this measurement has been highly dependent on the sample size and vessel configuration, while also being dependent on the agitation conditions (i.e., stagnant slurry systems have shown the ability to retain hydrogen given a potentially low indication of generation). With the low concentrations expected, it will also challenge existing on-line monitoring techniques. For SRS wastes, existing correlations of the radionuclide content to the hydrogen generation rate have been shown to be fairly effective and SRNL's recommendation would be that WTP pursue this approach in the future.

\subsection{Wear/Abrasion/Particle Hardness}

As materials are stored and/or transferred to and through WTP, abrasion or wear on various materials of construction is of interest and concern. The workshop discussions were primarily focused on wear and abrasion during transfer of the materials from the tank farm to WTP. During the workshop, high-level discussions were held regarding potential methods for measuring particle hardness, wear and/or abrasion in a radioactive environment. To SRNL's knowledge, there are no "off the shelf" test methods that have been employed for these types of measurement in radioactive environments. Specific methods discussed and of potential interest to evaluate their applicability included the techniques used by Dominion Engineering which performed erosion measurement for Bechtel and the Miller method (or a modified version). Future activities are being developed to specifically evaluate these specific methods or to develop alternative approaches to assess wear and abrasion issues during feed transfer from the TOC to WTP. 


\subsection{Glass Formulation}

A critical part of the WTP qualification process is the use of the glass product and process models to identify a blend that will meet both process and product performance constraints. The WTP qualification will utilize the most recent LAW and HLW glass algorithms to optimize the type and amount of glass forming materials to be mixed with the LAW and HLW feed streams. Once the glass formers are added, the mixtures will be melted to produce glass products to be analyzed via LA coupled with ICP-AES or MS. The compositional analysis of the glasses will then be used as input into the glass algorithms, and various process and product performance properties will be predicted to demonstrate acceptable glass products can be produced from both the LAW and HLW feed campaigns being qualified. In addition, WTP plans to evaluate the vitrified products for phase homogeneity or crystalline phase separation during waste qualification. Based on the meeting discussions, the WTP qualification process is limited to assessments based on predictions and not actual verification of any processing or durability properties. An inherent assumption in the process is that the models apply for the campaign to be processed. This is slightly different than the current approach that is used by DWPF. However, it should be pointed out that when DWPF was starting up there were concerns about model applicability over the projected composition region to be processed in DWPF so the compromise was to verify the models with each batch to ensure applicability. For WTP, as currently outlined, this portion of the qualification program would serve to provide a sample for subsequent analyses and as a confirmation that the batching process used during qualification (as opposed to the weighing/metering systems in the vitrification plants) was successful in targeting the glass composition of interest. Limited information would be gained by using SEM to evaluate for phase homogeneity or crystalline phase separation. If phase homogeneity or crystalline phase separation is a critical response to be measured, WTP may elect or need to consider other analytical tools for this assessment.

As previously discussed, there are similarities in the WTP approach and the work that SRNL performs in support of the sludge batch qualification efforts for DWPF. These include using glass algorithms to determine the glass forming materials (in SRNL's case this is a pre-fabricated frit) to be added to the sludge and the waste loading to be targeted; vitrifying the frit-sludge mixture to produce a glass product; analyzing the glass product (using ICP-AES or -MS coupled with a glass digestion instead of laser ablation); measuring glass properties and using the compositional analysis to predict various properties to assess model applicability and acceptability with respect to critical process and product performance constraints. The primary difference is that SRNL currently has two experimental programs (variability study and qualification sample) to verify that the glass product is acceptable and that the models being used are applicable.

\subsection{SRNL Comments and Observations}

Although various elements of the WTP qualification are consistent with (or at least similar to) the qualification programs developed and used by SRS in support of LAW and HLW treatment/processing operations, a few key points were identified that need to be considered for the future development and maturation of the WTP waste qualification program:

o The current waste qualification program may be "larger" than needed

This statement is made in the context of both the number of analytes required for the WAC-DQO and with respect to the proposed testing of all of the unit operations. It is 
understood that most (if not all) of the WAC-DQO criteria requiring analysis or qualification testing stems from either regulatory or mandated requirements. This list is more extensive than Savannah River's because SRS waste is not listed or considered mixed waste. SRNL also understands that WTP is continuing to work with its regulators and stakeholders to trim this list especially in cases where quality measurements are not practical and the data does not support the qualification of the final wasteform. As an example, if it can be shown that the targeted analyte will not survive the vitrification process or will be stabilized in the final wasteform and has minimal impact on the pretreatment and/or vitrification processes, then the added value of measuring the analyte is minimal.

With respect to the specific unit operations (e.g., sludge washing, ion exchange, CUF, and vitrification), WTP should perform critical reviews of existing data or evaluate the use of simulants to define operational bounds prior to the start of qualification to determine if a reduction in the overall testing program or streamlining of the program can be realized.

As the program matures and a number of campaigns have been processed, SRNL highly recommends that data developed through the WTP qualification testing be used to develop "technology off-ramps" that could minimize or eliminate certain analysis, calculations, or testing. The qualification data could be compared to facility operations or within the qualification data set to make this evaluation since operating information should be gained as the WTP processes different waste streams. Reevaluating the waste qualification program after actual facility data is in hand may allow WTP to streamline the overall qualification testing.

o The WTP pretreatment process and waste qualification will require thorough integration

There must be a direct and open line of communication between the engineers/scientists performing and generating the waste qualification data and those engineers that that are responsible for facility implementation. It has been SRNL's experience that technical experts are needed to not only generate specific qualification data but also to make critical decisions that may have an impact on downstream facility operations. In a typical DWPF sludge batch qualification effort, decisions are made throughout the process such as the washing or concentration endpoint that require working knowledge of the process or understanding of the potential impacts on the downstream process. SRNL has been performing batch qualification for more than 15 years and helped develop DWPF's baseline flowsheet; therefore, the technical knowledge for making the decisions is in hand and in effect the process is "proceduralized". Some time may be necessary for WTP's process to get to the same level and so open and extensive communication will be necessary.

As discussed in the meeting and emphasized by WTP, integration of the overall flowsheet will be key to the development and successful implementation of the qualification program. Integration ensures that material flow and balances proceed 
without deficiencies and the overall qualification program provides the required data to support WTP operations for each campaign. It also ensures that representative feed and/or potential recycle streams are fed into the upstream or downstream unit operation for evaluation. As the qualification program matures, integration of the specific unit operations (e.g., caustic and oxidative leaching, foaming potential, waste feed evaporation, treated LAW evaporation, ultrafiltration, Sr-TRU, settling rate (LAW), Cs ion-exchange, recycle from HLW/LAW off-gas, and HLW/LAW glass) as well as with the compliance plan must be performed.

o WTP and the TOC may have different definitions of representative samples

Based on the information presented during the workshop, the TOC has the responsibility to obtain and transmit a representative sample to WTP to support waste qualification efforts. Although that responsibility lies with the TOC, WTP should be monitoring the development and progress of any technology that is proposed or actually used to obtain the qualification sample to ensure it meets the needs and objectives of the waste qualification program. That is, if the qualification sample is not representative of any of the feed cuts or transfers ultimately coming into WTP, the data and operating parameters obtained from the qualification process may be of little, if any, value. SRNL recommends that WTP and the TOC ensure that the definition of "representative sample" is consistent between the two entities to mitigate potential downstream issues that may evolve due to differences in that definition. For the DWPF, Waste Acceptance Criteria are set and the Tank Farm has to demonstrate Waste Compliance criteria.

o Results from the qualification testing may not provide "optimal” facility operation parameters

Based on the workshop discussions, the intent of the qualification data was presented (or at least interpreted by SRNL attendees) in the context of "process optimization". That is, the data and parameters that would be generated by the waste qualification program would allow WTP to "optimally" run each major unit operation as defined on the Batch Sheet. Since that meeting, clarification from WTP has been made that the intent of the waste qualification program is to demonstrate or confirm the integrated flowsheet - not to optimize. Although there are some attributes of the Specification $12^{11}$ testing where trade-offs (or optimization efforts) are made between projected quantities of HLW glass and LAW glass, the overall intent of the waste qualification program should be to demonstrate the integrated flowsheet and to provide the data needed to efficiently process the wastes through the WTP - not optimization. As previously stated, the qualification process should be viewed as a confirmation and an opportunity to gain insight into the unexpected and offer insight into facility operations. It should not be viewed as a research and development program to generate innovative and technical information. 
Even if the qualification demonstration evolves smoothly, there is risk that the qualification results may not match actual process conditions for each unit operation due to issues such as scale-up or because of physical limitations of the WTP equipment as it becomes scaled or ages. SRNL has seen these differences in their testing versus actual DWPF operations as the equipment continues to age. This is why parametric studies are important for certain parts of the process in order to understand the sensitivity of the operational parameter to changes in compositions or physical properties.

o Required sample volume to support qualification analysis and testing may be significant

Based on the currently required number of analyses and suite of operational testing in the qualification program, the volume of sample could be significant. As the qualification programs matures, a key factor will be to define/refine the sample volume required for demonstrating the unit operations while also ensuring that all analyses are performed to meet the data quality objectives and processing parameter requirements.

o 180 day turn-around time may be challenging

Based on SRNL experience, the 180 day window to complete the qualification activities may prove to be aggressive (with respect to schedule) due to the complexity (number of analytical data needs, potential for matrix type approaches in unit operations testing to define facility operating parameters, etc.) of the qualification program. This concern would be greater with the initial qualifications as laboratories are coming up to speed and may be amplified if multiple Campaigns are being simultaneously qualified. With a single laboratory performing multiple qualifications at the same time, laboratory turnaround times may be strained or require multiple sets of laboratory scale test equipment, which may ultimately compromise the qualification schedule or drive up costs.

For the DWPF, the extensive testing that was performed for the initial sludge batches took between $8-10$ months for SRNL to complete and then DWPF had an additional $2-3$ months of paper work to complete before they could accept the batch. As more knowledge has been gained about the processes and the sludge behavior and analytical methods have been optimized and minimized, the qualification time has been reduced. However, the full suite of qualification efforts is still on the order of 4 -5 months with an additional 2 months of paper work for DWPF to complete. These reduced times do not lend themselves to many process upsets or leave room for much analytical error.

o Strong ties will need to be made between any updates to the models for glass composition and the waste qualification program. 
From SRNL's experience with the DWPF qualification program, the vitrification facility will require technically sound and compositionally applicable glass algorithms to ensure that the models being used to target specific glass formulations apply to the particular waste compositions being processed in each campaign. SRNL recognizes that the waste qualification program is not responsible for model development activities over the broad compositional range that is expected for the life of the WTP. However, WTP waste qualification program should take into account any model updates to ensure model validation encompasses the application region of interest.

\subsection{References}

1. A.V. Arakali, D.L. Banning, P.A. Benson, and D.A. Greer, "Initial Data Quality Objectives for WTP Feed Acceptance Criteria,” Bechtel, Richland, Washington, 24590WTP-RPT-MGT-11-014, Revision 0, 2011.

2. D.K. Peeler, D.J. Adamson, C.J. Bannochie, A.D. Cozzi, R.E. Eibling, M.S. Hay, E.K. Hansen, D.T. Herman, C.J. Martino, C.A. Nash, F.M. Pennebaker, M.R. Poirier, S.H. Reboul, M.E. Stone, K.M. Taylor-Pashow, T.L. White, and W.R. Wilmarth, "SRNL Phase 1 Assessment of the WAC/DQO and Unit Operations for the WTP Waste Qualification Program,” Savannah River National Laboratory, Aiken, South Carolina, SRNL-STI-2011-00274, 2011.

3. J.W. Olson, "ICD 19 - Interface Control Document for Waste Feed," Waste Treatment Plant, Richland, Washington, 24590-WTP-ICD-MG-01-019, Revision 5, 2011.

4. S.E. Campbell, "Qualification and Sampling Strategy for ISDP Batch 5 to Obtain Compliance to 512-S, DWPF, Tank Farm, and Saltstone Waste Acceptance Criteria,” XESR-H-00347, Revision 0, November 2011.

5. C.K. Chiu, "Waste Acceptance Criteria for Aqueous Waste Sent to the Z-Area Saltstone Production Facility,” X-SD-Z-00001, Revision 10, March 2011.

6. A.R. Shafer, "Waste Acceptance Criteria for Sludge, ARP, and MCU Process Transfers to 512-S and DWPF,” X-SD-G-00008, Revision 8 September 2011.

7. E.W. Harrison, "Waste Acceptance Criteria for Liquid Waste Transfers to the 241-F/H Tank Farms,” X-SD-G-00001, Revision 30, May 2011.

8. K.G. Brown, R.L. Postles, and T.B. Edwards, "Sme Acceptability Determination for DWPF Process Control," Savannah River National Laboratory, Aiken, SC, WSRC-TR95-00364, Rev. 5, 2006.

9. "Nuclear Waste Glass and Glass-Ceramic Product Consistency Test (PCT) Methods (ASTM C1285 Latest Revision)," Savannah River National Laboratory, Aiken, SC, ITS0009, Latest Revision. 
10. C.M. Jantzen, N.E. Bibler, D.C. Beam, C.L. Crawford, and M.A. Pickett, "Characterization of the Defense Waste Processing Facility (DWPF) Environmental Assessment (EA) Glass Standard Reference Material,” Westinghouse Savannah River Company, Aiken, SC, WSRC-TR-92-346, Rev. 1, 1993.

11. E. Slaathaug, "Specification 12 - Procedure to Determine the Waste Feed Treatment Approach,” Bechtel, River Protection Project, Waste Treatment Plant, Richland, Washington, 24590-WTP-RPT-PET-11-002, Revision A, 2011. 
SRNL-STI-2011-00723

Revision 0

Appendix A. Phase 1 Workshop Agenda 
Figure A-1. Phase 1 Workshop Agenda (July 18, 2011)

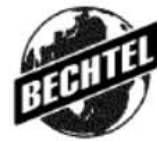

River Protection Project

Waste Treatment Plant

2435 Stevens Center Place

Richland, WA 99354

Tel: 5093712000

\section{Technology Exchange Workshop: Waste Pre-Qualification}

\section{Agenda}

Date: July 18, 2011

Time: $\quad$ 8:00am - 5:30pm

Location: PONA/1410-1412

Group Chair/Prepared By: J. Markillie

Goals/Objectives:

Day 1: Integrated WTP Pre-qualification Testing Approaches and Lessons Learned

\begin{tabular}{|c|c|c|c|}
\hline & Agenda Item/Issue & Time & Lead \\
\hline 1. & Welcome and Safety Topic & $8: 00$ & Matis \\
\hline 2. & $\begin{array}{l}\text { Overview of WTP approach to feed WAC/pre- } \\
\text { qualification and process control }\end{array}$ & $8: 15$ & Markillie \\
\hline 3. & IVTP Treatment Process Overview & $8: 45$ & Matis \\
\hline 4. & Break & $9: 45$ & \\
\hline 5. & $\begin{array}{l}\text { Overview of WTP DQO Effort and WTP pre- } \\
\text { qualification plan }\end{array}$ & $10: 00$ & Arakali \\
\hline \multirow[t]{5}{*}{6.} & $\begin{array}{l}\text { Group discussion: Approach for Cs IX RF testing. } \\
\text { Working lunch at 12:00 }\end{array}$ & 11:00 & \\
\hline & - Describe WTP approach to pre-qualification & & Arakali \\
\hline & $\begin{array}{l}\text { - Identify SRNL pre-qualification/testing lessons } \\
\text { learned }\end{array}$ & & SRNL \\
\hline & - Identify gaps and discuss & & SRNL \\
\hline & $\begin{array}{l}\text { Identify methods, practical implementation issues, } \\
\text { methods improvement, scaling/conditions }\end{array}$ & & SRNL \\
\hline 7. & Break & 1:00 & \\
\hline \multirow[t]{5}{*}{8.} & $\begin{array}{l}\text { Group discussion: Approach for HLW and LAWV glass } \\
\text { formulation testing }\end{array}$ & $1: 15$ & \\
\hline & - Describe WTP approach to pre-qualification & & Arakali \\
\hline & $\begin{array}{l}\text { - Identify SRNL pre-qualification/testing lessons } \\
\text { learned }\end{array}$ & & SRNL \\
\hline & - Identify gaps and discuss & & SRNL \\
\hline & $\begin{array}{l}\text { Identify methods, practical implementation issues, } \\
\text { methods improvement, scaling/conditions }\end{array}$ & & SRNL \\
\hline
\end{tabular}


Figure A-1. Phase 1 Workshop Agenda (July 18, 2011) (continued)
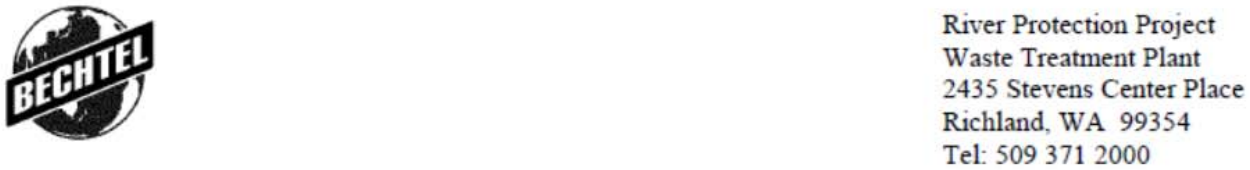

\section{Technology Exchange Workshop: Waste Pre-Qualification Agenda}

$\begin{array}{ll}\text { Date: } & \text { July 18, } 2011 \\ \text { Time: } & \text { 8:00am - 5:30pm } \\ \text { Location: } & \text { PONA/1410-1412 }\end{array}$

Agenda Item/Issue

- Rheology of material after glass former addition

9. Break

10. Group discussion: Other Testing Criteria / Strategies

(Discussions to include SRNL inputs and lessons learned for methods, practical implementation issues, and test parameters)

- Hydrogen and Ammonia generation rates

- Abrasivity measurement / Particle hardness / Vessel erosion

- Sodium concentration monitoring

- Criticality Safety Control Measurements (fissile Pu, $U$, neutron absorbers, ...)
Time

Lead

$3: 15$

$3: 30$

Arakali / SRNL

11. Adjourn

Markillie 
Figure A-2. Phase 1 Workshop Agenda (July 19, 2011)

River Protection Project

Waste Treatment Plant

2435 Stevens Center Place

Richland, WA 99354

Tel: 5093712000

\section{Technology Exchange Workshop: Waste Pre-Qualification}

\section{Agenda}

Date:

July 19,2011

Time: $\quad 8: 00 \mathrm{am}-5: 30 \mathrm{pm}$

Location: PONA/1410-1412

Group Chair/Prepared By: J. Markillie

Goals/Objectives:

Day 2: Integrated WTP Pre-qualification Testing Approaches, Lessons Learned, and Staged Feed Scenarios

\begin{tabular}{|c|c|c|c|}
\hline & Agenda Item/Issue & Time & Lead \\
\hline 1. & Welcome and Safety Topic & 8:00 & Markillie \\
\hline \multirow[t]{5}{*}{2.} & Group discussion: Approach for sludge wash testing & $8: 15$ & \\
\hline & - Describe WTP approach to pre-qualification & & Arakali \\
\hline & $\begin{array}{l}\text { - Identify SRNL pre-qualification/testing lessons } \\
\text { learned }\end{array}$ & & SRNL \\
\hline & - Identify gaps and discuss & & SRNL \\
\hline & $\begin{array}{l}\text { - Identify methods, practical implementation issues, } \\
\text { methods improvement, scaling/conditions }\end{array}$ & & SRNL \\
\hline 3. & Break & $10: 15$ & \\
\hline \multirow[t]{5}{*}{4.} & $\begin{array}{l}\text { Group discussion: Approach for aluminum and } \\
\text { chromium leaching - caustic and oxidative leaching }\end{array}$ & $10: 30$ & \\
\hline & - Describe WTP approach to pre-qualification & & Arakali \\
\hline & $\begin{array}{l}\text { - Identify SRNL pre-qualification/testing lessons } \\
\text { learned }\end{array}$ & & SRNL \\
\hline & - Identify gaps and discuss & & SRNL \\
\hline & $\begin{array}{l}\text { - Identify methods, practical implementation issues, } \\
\text { methods improvement, scaling/conditions }\end{array}$ & & SRNL \\
\hline 5. & Working Lunch & $12: 30$ & \\
\hline 6. & $\begin{array}{l}\text { Overview staging and transfer of supernate and } \\
\text { supernate/sludge from Tank Farms }\end{array}$ & $12: 30$ & $\begin{array}{l}\text { WRPS: Saunders / } \\
\text { Larson }\end{array}$ \\
\hline 7. & Break & $1: 30$ & \\
\hline 8. & $\begin{array}{l}\text { Group discussion: Approach for cross-flow filtration } \\
\text { testing. }\end{array}$ & $1: 45$ & \\
\hline
\end{tabular}


Figure A-2. Phase 1 Workshop Agenda (July 19, 2011) (continued)

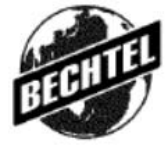

River Protection Project

Waste Treatment Plant

2435 Stevens Center Place

Richland, WA 99354

Tel: 5093712000

\section{Technology Exchange Workshop: Waste Pre-Qualification}

\section{Agenda}

Date:

July 19, 2011

Time:

8:00am - 5:30pm

Location: PONA/1410-1412

Agenda Item/Issue

- Identify SRNL pre-qualification/testing lessons learned

- Identify gaps and discuss

- Identify methods, practical implementation issues, methods improvement, scaling/conditions

9. Break

10. Group discussion: Other Testing Criteria / Strategies

(Discussions to include SRNL inputs and lessons learned for methods, practical implementation issues, and test parameters)

- Waste Concentration / Boildown / Foaming conditions / Precipitation potential

- Rheology / wt\% Solids / Particle size and distribution

- Feed compatibility / Recycles / Heels / Blending strategy

11. Adjourn
Time

Lead

SRNL

SRNL

SRNL

$3: 45$

4:00

Arakali / SRNL 
Figure A-3. Phase 1 Workshop Agenda (July 20, 2011)

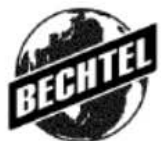

River Protection Project

Waste Treatment Plant

2435 Stevens Center Place

Richland, WA 99354

Tel: 5093712000

\section{Technology Exchange Workshop: Waste Pre-Qualification}

\section{Agenda}

Date: $\quad$ July 20,2011

Time: $\quad$ 8:00am-4:30pm

Location: PONA/1410-1412

Group Chair/Prepared By:

Goals/Objectives:

Day 3: Integrated WTP Pre-qualification Testing Approaches, Lessons Learned

\begin{tabular}{|c|c|c|c|}
\hline & Agenda Item/Issue & Time & Lead \\
\hline 1. & Welcome and Safety Topic & $8: 00$ & Markillie \\
\hline 2. & $\begin{array}{l}\text { SRS pre-qualification for Tank Farm - SCIX-Saltstone } \\
\text { process and pre-qualification lessons learned }\end{array}$ & $8: 15$ & SRNL \\
\hline 3. & Break & $9: 30$ & \\
\hline 4. & $\begin{array}{l}\text { SRS pre-qualification for Tank Farm - ARP/MCU- } \\
\text { DUVF process and pre-qualification lessons learned }\end{array}$ & $9: 45$ & SRNL \\
\hline 5. & $\begin{array}{l}\text { Integration of Pre-qualification testing operations. } \\
\text { Group discussion to determine means to integrate the } \\
\text { testing unit operations into a system. }\end{array}$ & $10: 45$ & SRNL \\
\hline 6. & Working Lunch & $12: 00$ & \\
\hline \multirow[t]{4}{*}{7.} & $\begin{array}{l}\text { Group discussion: Identify and discuss gaps and } \\
\text { lessons learned with supernate and supernate/sludge } \\
\text { pre-qualification activities }\end{array}$ & $12: 00$ & \\
\hline & $\begin{array}{l}\text { - Identify SRNL pre-qualification/testing lessons } \\
\text { learned }\end{array}$ & & SRNL \\
\hline & - Identify gaps and discuss & & SRNL \\
\hline & $\begin{array}{l}\text { - Identify methods, practical implementation issues, } \\
\text { methods improvement, scaling/conditions }\end{array}$ & & SRNL \\
\hline 8. & Break & $2: 30$ & \\
\hline 9. & $\begin{array}{l}\text { Discuss Other Testing Criteria / Strategies remaining } \\
\text { from Monday and Tuesday }\end{array}$ & $2: 45$ & \\
\hline 10. & Workshop summary & $4: 00$ & Markillie \\
\hline 11. & Adjourn & $4: 30$ & Markillie \\
\hline
\end{tabular}




\section{Distribution:}

\section{SRNL}
A. B. Barnes, 999-W
A. P. Fellinger, 773-41A
S. D. Fink, 773-A
B. J. Giddings, 786-5A
J. C. Griffin, 773-A
C. C. Herman, 999-W
S. L. Marra, 773-A
F. M. Pennebaker, 773-42A
W. R. Wilmarth, 773-A
D.J. Adamson, 786-5A
C. J. Bannochie, 773-42A
A.D. Cozzi, 999-W
R.E. Eibling, 999-W
M.S. Hay, 773-42A
E.K. Hansen, 999-W
D.T. Herman, 735-11A
C.J. Martino, 773-42A
C.A. Nash, 773-42A
D. K. Peeler, 999-W
M.R. Poirier, 773-42A
S.H. Reboul, 773-A
M.E. Stone, 999-W
K.M. Taylor-Pashow, 773-A
T.L. White, 773-A

\section{WTP}
A. Arakali, MS 12-2B
P. Benson, MS 10-B
T. Halverson, MS 12-2B
M. Hamlet, MS 10-E
D. Herting, MS 17-A
J. Johnston, MS 10-E
T. Lane, MS 10-E
J. Markillie, MS 12-2B
G. Matis, MS 12-2B
M. Miller, MS 12-2B 